This is the author's accepted manuscript of the article published in Current Pharmaceutical Design. The final authenticated version is available online at: https://doi.org/10.2174/1381612827666210728103524

Cite this article as:

Semwal Shubham , Boukherroub Rabah, Savvides N. Savvas and Bouckaert Julie*, Natural Antibodies: Protecting Role of IgM in Glioblastoma and Brain Tumours, Current Pharmaceutical Design 2021; 27(45) . https://dx.doi.org/10.2174/1381612827666210728103524

\title{
Natural antibodies: Protecting role of IgM in glioblastoma and brain tumours
}

\author{
Shubham Semwal ${ }^{1}$, Rabah Boukherroub ${ }^{2}$, Savvas N. Savvides ${ }^{3}$, Julie Bouckaert ${ }^{1} *$
}

1 Unité de Glycobiologie Structurale et Fonctionnelle, UMR 8576 from the CNRS and the University of Lille, 50 Avenue Halley, 59650 Villeneuve d'Ascq, France

${ }^{2}$ Univ. Lille, CNRS, Centrale Lille, Univ. Polytechnique Hauts-de-France, UMR 8520 - IEMN, F-59000 Lille, France

${ }^{3}$ Unit for Structural Biology, VIB - UGent Center for Inflammation Research, Department of Biochemistry and Microbiology, Ghent University, Technologiepark 71, 9052 Ghent, Belgium

Shubham Semwal <shubham.semwal@ univ-lille.fr> 0000-0002-6941-5103

Rabah Boukherroub <rabah.boukherroub@univ-lille.fr> 0000-0002-9795-9888

Savvas N. Savvides <Savvas.Savvides@UGent.be> 0000-0003-3420-5947

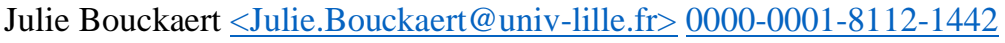




\section{Abstract}

Background: Glioblastoma is a grade IV astrocytoma with an average survival span for patients of 18 months after initial diagnosis and no standard treatment protocol. There is a need to look at novel approaches to target glioblastoma.

Objectives: This review intends to capture the role of immunoglobulin-M in cancer, more specifically in glioblastoma multiforme (GBM), and to compile the latest developments and immunological pathways relevant to glioblastoma

Methods: Information on glioblastoma, cancer microenvironment, cancer therapeutics and how to improve the scenario was obtained from scientific literature databases such as Pubmed, Medline, Google Scholar, Science Direct, Springer, Wiley online library and some data was harvested from regulatory and compliance databases such as clinicaltrials.gov, FDA database, WHO Globocan.

Results and conclusions: Currently, only a limited number of therapies are approved for GBM, and no standard of care is in place in case of disease relapse, necessitating a possible broader perspective in looking at the disease and its underlying mechanisms.

Keywords: IgM, Glioblastoma, Natural Antibodies, Immunotherapy, Microglia, ALK. 


\section{Introduction}

The World Health Organization (WHO) defines cancer as a large group of diseases leading to uncontrollable and abnormal cell growth, spreading across the whole body or neighbouring tissues.
According to the GLOBOCAN 2020, an online database from WHO, the global cancer burden lies around 19.3 million people with a mortality index of over 10 million deaths [1] (Fig.1).

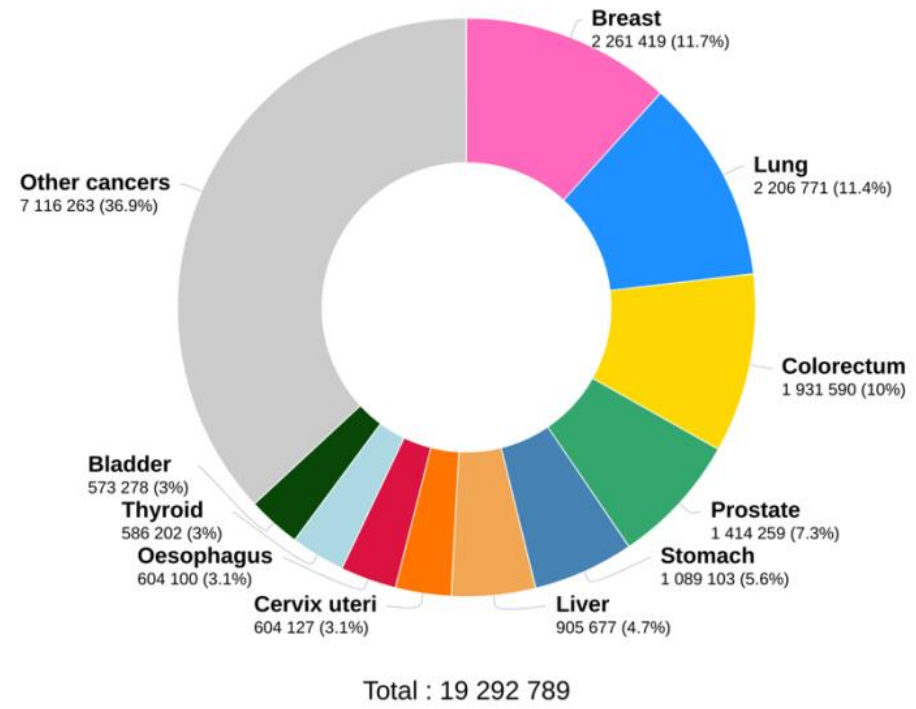

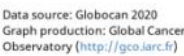

tal : 19292789

Figure 1: Estimated number of new cases of different types of cancer in 2020 all across the world [1].

On average, every fifth person develops cancer during their lifetime, with men having poorer survival odds [1]. Although not one of the leading cancers in terms of incidence or prevalence, brain cancer is currently ranked fourth in terms of the number of years of life lost. It is estimated that
308,102 people were diagnosed with brain cancer in the year 2020, out of which 251,329 succumbed to the tumour. These numbers put the current rate of fatalities at $81.5 \%$, which is expected to reach $85.15 \%$ in the next 20 years with a $25.9 \%$ increase in the incidence[1] (Fig. 2). 


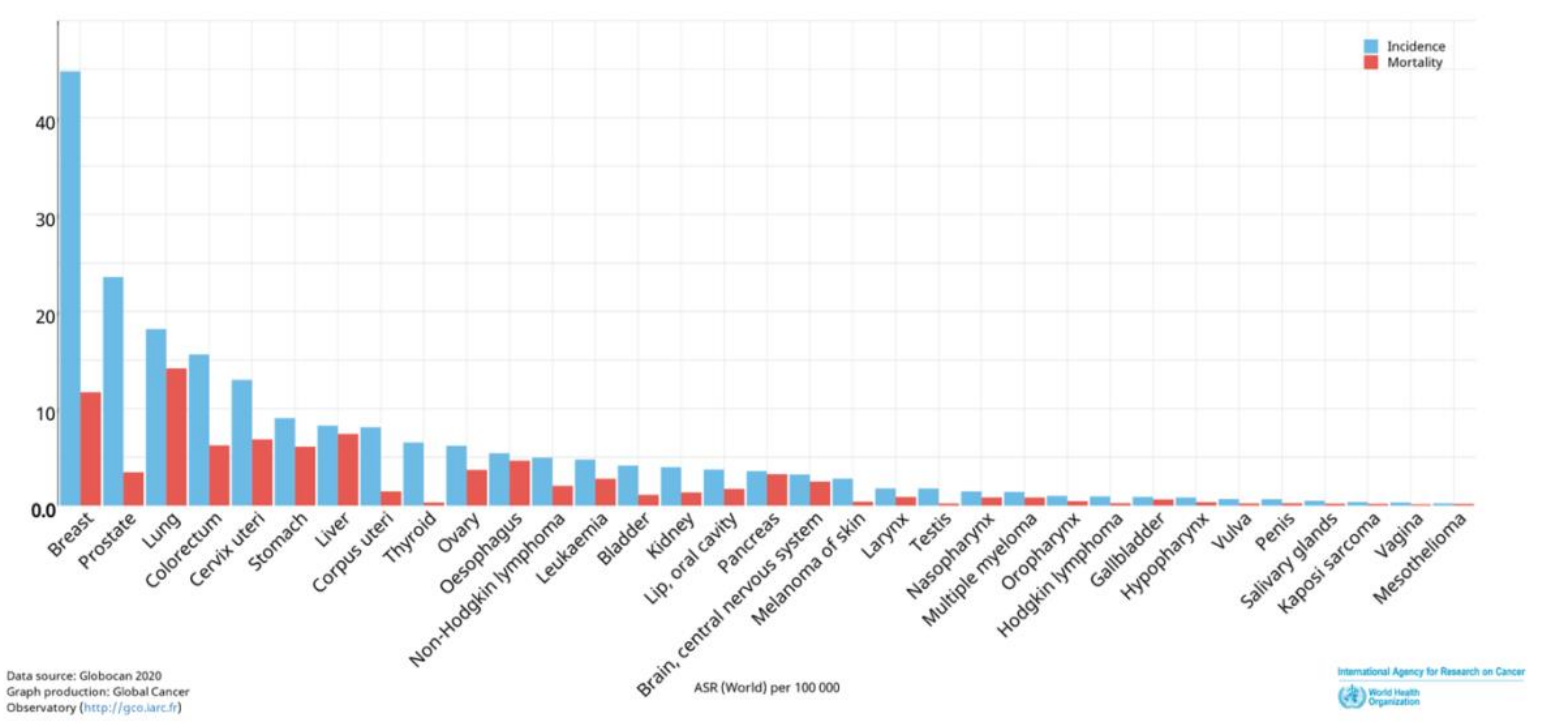

Figure 2. Graph depicting estimated age-standardised incidence and mortality rates across the world in the year 2020 for different types of tumours. The parameters include both sexes and ages between 0-74 years of age. The highest mortality to incidence ratio is clearly visible for three types of cancers, viz. liver, pancreas and brain or CNS [1].

Among brain cancer patients, about $27 \%$ suffer from glioma, a tumour consisting mainly of malignant glial cells. As per WHO classification, gliomas are classified and graded from type I to IV consisting of astrocytoma (I-IV), oligodendroglioma (grade IIIII), mixed oligoastrocytoma (grade I-III), and ependymal tumours (grade I-II) [2]. Glioblastoma, also sometimes referred to as glioblastoma multiforme (GBM), is a special type of grade IV glioma defined by its anaplastic cellular nature with pleomorphic astrocytic cells with marked nuclear atypia and high mitotic rates. Primary glioblastoma starts straight from stage IV without showing any prior changes, whereas secondary glioblastoma is formed when a lower grade astrocytoma reaches grade IV [2, 3]. Nevertheless, except for a few genotypical changes, the overall expression of surface markers in primary and secondary glioblastoma are the same [3]. Therefore, genotyping glioblastoma is necessary to facilitate the appropriate choice of therapeutic approaches, which may lead to better survival rates [2-5].

\subsection{Current therapies for glioblastoma}

The primary step in standard health care for glioblastoma, like most of the other brain tumours, is dependent upon maximal resection of the tumour by surgery. Indeed, over the years, many studies have established that a higher subtotal and gross total resection is necessary for better survival chances [6, 7]. Apart from a better survival ratio, resection also serves some key factors such as reduction in tumour volume (lower chemotherapy needed), tumour genotyping (to identify the correct approach), and accurate histological diagnosis (type of brain cancer). To improve the surgical resection of GBM, 5-ALA (5-aminolevulinic acid, brand name Gliolan) was approved by FDA in 2017 [8]. 5ALA is part of the mammalian heme biosynthetic pathway that cells metabolise and transform through a series of reactions in the mitochondria into protoporphyrin IX, a fluorescent metabolite [9]. Fluorescence-guided tumour resection surgery has gained much popularity because the administration of 5-ALA a couple of hours before anaesthesia 
allows the intraoperative visualisation of malignant glioma cells $[8,10]$. Although surgical resection is essential, it is commonly not the only method of care. It is usually accompanied by radiotherapy and chemotherapy. Radiotherapy has been used for a long time to reduce tumour size and improve control. The general dose of radiation given is a maximum of 60 Gy at a dose of 2 Gy - five days a week for six weeks accompanied with temozolomide treatment (Table 1). Temozolomide is the most widely used chemotherapy drug, usually given at $75 \mathrm{mg} / \mathrm{m}^{2}[11,12]$. Due to recent advancements in treating GBM, the FDA approved Tumour Treating Field (TTF) back in 2011 as an adjuvant therapy alongside the standard of care therapeutics[13]. TTF is given by a device known as Optune $^{\circledR}$, which generates a low intensity, intermediate frequency $(200 \mathrm{kHz})$ at $1-2 \mathrm{~V} / \mathrm{cm}^{2}$ of the patient's scalp to induce anti-tumour effect via anti-microtubule action[12]. TTF has proven remarkable success in GBM treatment with only a minor side effect of making the patient suffer from mild to moderate dermatitis due to the recommended long-time duration (18h/day)[14]. On the contrary side of the spectrum, the EF-14 trial demonstrated no difference in health-related quality of life with the use of TTF apart from increased itchy skin[15]. These two separate sides make use of TTF quite controversial despite its FDA approval about a decade ago.

Table 1: List of FDA approved drugs for brain tumours.

\begin{tabular}{|c|c|c|c|c|c|}
\hline $\begin{array}{c}\text { Therapeutic } \\
\text { agent }\end{array}$ & Mechanism & Manufacturer & Approved for & $\begin{array}{c}\text { Date of } \\
\text { Approval }\end{array}$ & Reference \\
\hline $\begin{array}{c}\text { Afinitor } \\
\text { (Everolimus) }\end{array}$ & $\begin{array}{l}\text { mTOR inhibitors or } \\
\text { inhibitor of FK506- } \\
\text { binding protein 12- } \\
\text { rapamycin-associated } \\
\text { protein } 1 \text { (FRAP1) }\end{array}$ & $\begin{array}{l}\text { Novartis } \\
\text { Biocon }\end{array}$ & $\begin{array}{l}\text { Renal carcinoma } \\
\text { Renal graft rejection } \\
\text { Subependymal giant cell } \\
\text { astrocytoma (SEGA) under } \\
\text { special circumstances } \\
\text { Metastatic pancreatic } \\
\text { neuroendocrine tumours not } \\
\text { surgically removable } \\
\text { Breast cancer in postmenopausal } \\
\text { women with HER-2 negative } \\
\text { cancer } \\
\text { Graft rejection in hepatic } \\
\text { transplant } \\
\text { Tuberous sclerosis complex }\end{array}$ & $\begin{array}{l}(2009) \\
(2010) \\
(2011) \\
(2012) \\
(2013) \\
(2018)\end{array}$ & $\begin{array}{l}16] \\
{[17]} \\
{[18]} \\
{[19]}\end{array}$ \\
\hline $\begin{array}{l}\text { Afinitor Disperz } \\
\text { (Everolimus) }\end{array}$ & mTOR inhibitors & Zortress & same as Everolimus & & \\
\hline $\begin{array}{c}\text { Avastin } \\
\text { (Bevacizumab) }\end{array}$ & $\begin{array}{c}\text { Humanised } \\
\text { monoclonal antibodies } \\
(\mathrm{mAb}) \text { against VEGF }\end{array}$ & $\begin{array}{l}\text { Genetech- } \\
\text { Roche }\end{array}$ & $\begin{array}{c}\text { Cervical Cancer } \\
\text { Colorectal Cancer } \\
\text { Glioblastoma } \\
\text { Hepatocellular carcinoma } \\
\text { Nonsquamous non-small cell } \\
\text { lung cancer } \\
\text { Ovarian epithelial, fallopian } \\
\text { tube, or primary peritoneal } \\
\text { cancer } \\
\text { Renal cell carcinoma }\end{array}$ & $\begin{array}{c}\text { (June 2006) } \\
\text { (May 2009) } \\
(2006) \\
(2018) \\
(2007)\end{array}$ & {$[20,21]$} \\
\hline $\begin{array}{c}\text { BiCNU } \\
\text { Carmustine }\end{array}$ & alkylating agent & $\begin{array}{c}\text { Emcure } \\
\text { Pharmaceuticals }\end{array}$ & $\begin{array}{c}\text { Brain tumours } \\
\text { Hodgkin Lymphoma } \\
\text { Non-Hodgkin lymphoma }\end{array}$ & (July 1977) & {$[22]$} \\
\hline
\end{tabular}




\begin{tabular}{|c|c|c|c|c|c|}
\hline $\begin{array}{l}\text { Gliadel Wafer } \\
\text { (Carmustine } \\
\text { Implant) }\end{array}$ & $\begin{array}{l}\text { direct delivery of } \\
\text { crusting in the } \\
\text { extracellular fluid of } \\
\text { the brain }\end{array}$ & $\begin{array}{c}\text { Guilford } \\
\text { Pharmaceuticals }\end{array}$ & $\begin{array}{l}\text { Recurred GBM } \\
\text { Malignant Glioma }\end{array}$ & 1996 & [23] \\
\hline Lomustine & $\begin{array}{l}\text { alkylating nitrosourea } \\
\text { compound }\end{array}$ & $\begin{array}{l}\text { Bristol-Myers } \\
\text { Squib (prior } \\
\text { owner) } \\
\text { NextSource } \\
\text { (Since 2013) }\end{array}$ & $\begin{array}{c}\text { Brain tumour } \\
\text { Hodgkin lymphoma }\end{array}$ & $\begin{array}{l}1976 \\
2013\end{array}$ & [24] \\
\hline $\begin{array}{c}\text { Temodar } \\
\text { (Temozolomide) }\end{array}$ & $\begin{array}{l}\text { alkylating/Methylating } \\
\text { agent }\end{array}$ & Merck \& Co. & $\begin{array}{l}\text { Anaplastic astrocytoma } \\
\text { Glioblastoma multiforme }\end{array}$ & $\begin{array}{l}\text { Nov. } 1999 \\
\text { March } 2005\end{array}$ & $\begin{array}{l}{[25]} \\
{[26]}\end{array}$ \\
\hline
\end{tabular}

Glioblastoma is known for its high relapse rate, and yet there is no standard of care procedure acceptable for relapsing patients as only a few of them can take secondary treatment. Due to the resistance of GBM cells to the treatment as well as the highly invasive nature of these cells, a very poor survival rate of 5 years in only about $5 \%$ of cases can be achieved. This has prompted efforts to better understand the tumour microenvironment as well as consideration of new approaches to treat GBM, such as immunotherapy.

Immunotherapy is rapidly becoming a pillar of anticancer therapy by harnessing the power of the host's immune system by inducing, enhancing, or suppressing immune responses to reject cancer cells. Immunotherapeutic approaches can be classified as active immunotherapy aimed at promoting a Th1 immune response through tumour vaccines, nonspecific immune stimulants, cellular vaccines, and as passive immunotherapy to induce an antitumour effect by transferring effector immune cells into patients. The first antigen-specific vaccine for castration-resistant prostate cancer, sipuleucel-T, was approved by the FDA in 2010[27]. A year later, the first checkpoint inhibitor for advanced melanoma, ipilimumab, was approved[27].

Tumour vaccines are made against tumour-specific antigens (TSA) that are primarily present only on tumour cells. The TSAs that arise from mutations of genes in the cancer cells are good candidates as suitable vaccine agents, given that such variants are absent in normal cells, thus making them safe to use.
In theory, a TSA vaccine should not elicit any response against normal cells but would be expected to be effective against tumour cells. Epidermal Growth Factor Receptor variant III, commonly referred to as EFGRvIII, is a mutated version of EFGR lacking exon 2-7 (deletion), which renders it a unique amino acid sequence. This mutation renders cancer cells carrying this mutation with a truncated protein carrying an altered extracellular domain epitope [28]. This led to the development of Rindopepimut, a 13-amino acid EGFRvIII peptide vaccine conjugated with an adjuvant whose PhaseIII clinical trials were recently completed successfully in 2017 [29, 30]. Although Rindopepimut demonstrated great potential during its phase II clinical trial, resulting in increased overall survival correlated with the magnitude of induced tumour immunity [27, 31], it failed to show any drastic improvement in the patient's survival with newly diagnosed glioblastoma [29].

Another promising target for tumour vaccine development would be Anaplastic Lymphoma Kinase (ALK). The full-length ALK of $\sim 220 \mathrm{kDa}$, including post-translational modifications like $\mathrm{N}$ glycosylation, belongs to the receptor tyrosine kinase (RTK) [32]. Its intracellular C-terminal kinase domain is connected to several extracellular domains via a single transmembrane helix receptor [33]. ALK has been linked to cell development and differentiation, and its quantity starts decreasing as the gestation period increases, leaving ALK only in a few tissues, including the brain, testis, small 
intestine, etc. Point mutations were found in ALK from different tumours, including neuroblastoma and glioblastoma [34]. In 2011, the FDA approved crizotinib as the first RTK inhibitor vaccine for nonsmall-cell lung cancer (NSCLC), but this drug exhibited serious side effects and a decrease in pharmacokinetic delivery due to its limited ability to cross the brain-blood barrier. This led to the development and repurposing of second-generation drugs like ceritinib, brigatinib and alectinib [35]. The major problem with ALK inhibitors is similar to other cancer vaccines, as cancer patients tend to develop resistance after treatment, making it problematic for cancer treatment in relapsing cases. The third generation of ALK inhibitors, lorlatinib and brigatinib, have been proposed to re-sensitise tumour cells to second-generation ALK inhibitors. Lorlatinib was approved by FDA in 2015 for NSCLCs and in 2018 for $2^{\text {nd }}$ and $3^{\text {rd }}$ line treatment of metastatic NSCLC. However, clinical trials are still ongoing for brigatinib, while some initial success was reported with lorlatinib [36-38]. The two examples mentioned above of rindopepimut and ALK inhibitors suggest that different approaches need to be developed to treat glioblastoma. Targeted immunotherapy in GBM is still in its infancy and matures at a slower but steady rate [39].

\section{Cancer Immunology}

The immune system has evolved to recognise invading pathogens. Understanding how it recognises and mounts a coordinated immune response to naturally occurring alterations of selfantigens during mutagenesis is ongoing. Most cells undergo transcriptional and translational mutations approximately 1,000-10,000 times per day, and even more frequently if a mutation successfully causes the cell to escape intrinsic repair mechanisms. The latter entails cases whereby an intact immune system can suppress this escape, known as extrinsic tumour suppressor mechanisms
[40, 41]. Therefore, after an abnormal cell escapes intrinsic tumour suppressor mechanisms, it is imperative that it has a second line of defence that rapidly recognises these abnormal cells. In a healthy individual, the adaptive immune system consisting of B-cells, T-cells, dendritic cells, macrophages, and many more constantly roam across the human body and look out for the mutated and thus potential cancer cells to destroy them.

\subsection{Immune surveillance in cancer}

Immune surveillance is a natural process, which involves special types of WBCs called Natural Killer (NK) cells and T-cells to recognise the antigen provided by the cells using their MHC-I receptors. Under normal conditions, cells express self-proteins which are recognised by immune cells, thereby maintaining the cells healthy. When there is an anomaly such as a mutation in DNA during replication or damage to the cell due to radiation exposure or other causes, the cells start displaying specific molecules on the MHC-I as well as on receptors present on their surface, flagging them as stress signals. This makes them recognisable by $\mathrm{T}$ cells, leading to the removal of the affected cells by apoptosis or phagocytosis. The NK cells have specialised receptors like NKG2D, a C-type lectinlike receptor that binds to stress signals and releases perforins and granzymes alongside cytotoxic T-cells that are activated by dendritic cells (DC) [42-44]. These molecules initiate a signalling cascade inside the tumour cells, causing apoptosis, assigning a major role to T-cells and NK cells in the process. As tumours evolve, they become heterogeneous by undergoing genetic changes that affect their surface receptors. Due to these changes, certain cells acquire the ability to evade the immune responses as they reduce MHC-I receptors on the cell and sometimes express certain immunosuppressive molecules like PDL1 (Protein-Death Ligand) that bind and 
consequently inactivate the PD1 receptor on cytotoxic T-cells [45-47]. This process is known as immune editing, which consists of elimination, equilibrium, and escape. When tumour cells reach the escape phase, they are generally immune-edited to such an extent that they show high amounts of inhibitory checkpoint receptors, like PDL-1, that in turn shut down all the T-cells helping the cancer cells to evade the hosts' defence system [48]. Certain modern immunotherapies focus on dealing with tumours by either shutting down the immune checkpoints on specific T-cells or by making T-cells that can specifically target antigens on immuneedited tumours [49].

\subsection{Tumour microenvironment of GBM and}

\section{immune evasion mechanisms}

In GBM, the tumour microenvironment is provided with immunosuppressive molecules that facilitate evasion of the natural immune response (Table 2 ). Cytokines such as Interleukin (IL)-1, IL-6, IL-10, prostaglandin E2 (PGE2), basic fibroblast growth factor (bFGF), and transforming growth factor (TGF- $\beta$ ) are produced in the GBM tumour microenvironment to promote tumorigenesis and suppress the immune response against tumours [4951]. The GBM microenvironment also uses CD70, a ligand for CD27 and a member of the TNF receptor family of proteins, that elicits $\mathrm{T}$-cell apoptosis by different mechanisms. Gangliosides and CD70 have been known to increase the tendency of T-cells to undergo apoptosis significantly. It is partially dependent on the receptor-dependent pathway as it is hypothesised that overexpression of CD70 on tumour cells triggers T-cell apoptosis; gangliosides are also related to immunosuppression, and T-cell apoptosis as T-cell apoptosis was found to decrease when ganglioside and CD70 functions were blocked [52-54]. Alongside CD27, programmed cell death protein-1 (PDL-1) ligand and FasL are also expressed on the surface of glial cells, which, as described earlier, can cause T-cell apoptosis [55]. The GBM microenvironment deals with angiogenesis and Treg (Regulatory T-cell) activation to further enhance tumour growth. As tumour cells grow rapidly, a hypoxic condition is created around the cells, enabling the GBM microenvironment to activate the Signal Transducer and Activator of Transcription 3 (STAT3), an immunosuppressive pathway and potent regulator of anti-inflammatory responses. STAT3 triggers the synthesis of hypoxia-inducible factor-1 (HIF-1), that subsequently induces activation of Tregs and production of vascular endothelial growth factor (VEGF) and promotes GBM cancer stem cells. Additionally, hypoxic conditions in the CNS trigger the transformation of macrophages into TumourAssociated Macrophages (TAM), leading to a feedforward mechanism of tumour-mediated immunosuppression $[53,54,56,57]$. These types of TAM that support tumour growth are termed M2 cells, while the term 'M1' is used to annotate antitumour macrophages that are activated by the classical pathway involving interferon- $\gamma$ [58].

Tumour cells have several mechanisms in their arsenal to evade the host's natural defence against tumour cells. In GBM, there are several mechanisms that prevent the clearance of defective tumour cells from the body. The tumour microenvironment plays a major role in providing the evasion mechanism as described earlier, but there are few other factors that aid the tumour cells. One such mechanism is modulating antigen presentation. GBM cells also stimulate the secretion of anti-inflammatory IL-10 and inhibit the production of TNF- $\alpha$ by microglia, further promoting suppression of the immune response (Table 2) [57]. Under certain conditions, central nervous system (CNS) antigens were detected in the perivascular space, indicating that these antigens can interact with immune cells like Tcells and DCs in cervical lymph nodes, thus providing a site for tumour antigen presentation [53, 59]. 
Table 2: List of molecules present in the GBM microenvironment and their role in immune evasion.

\begin{tabular}{|c|c|c|c|c|}
\hline No. & Component & Source of Origin & Effect on GBM & Reference \\
\hline 1 & IL-1ß & GBM microglia & $\begin{array}{l}\uparrow E R K / M A P K \text { activity; } \uparrow \text { VGEF; } \uparrow \text { JNK \& } \\
\text { sphingosine kinase activity; } \uparrow \text { p38 MAPK } \\
\text { activity; } \uparrow \text { drug resistance; } \uparrow \text { stemness factor } \\
\text { gene; } \uparrow \text { IL-6 production. }\end{array}$ & {$[51,60,61]$} \\
\hline 2. & IL-6 & $\begin{array}{l}\text { GBM microglia and } \\
\text { plasma of GBM } \\
\text { patient }\end{array}$ & $\begin{array}{l}\text { IL-6` mouse fails to develop GBM; } \\
\uparrow \mathrm{JAK} / \mathrm{STAT} 3 \text { activation; } \uparrow \text { tumour } \\
\text { heterogeneity; } \uparrow \text { stemness; } \uparrow \text { migration and } \\
\text { evasiveness; } \uparrow \text { heterogeneity }\end{array}$ & {$[61]$} \\
\hline 3. & IL-8 & GBM microglia & $\begin{array}{l}\uparrow \text { proliferation and evasiveness; } \uparrow \text { angiogenesis; } \\
\uparrow \text { tumour growth in autocrine manner }\end{array}$ & {$[61]$} \\
\hline 4. & IL-10 & TAM & $\begin{array}{l}\uparrow \text { immune suppression; } \uparrow \text { tumour growth; } \uparrow \text { Tregs; } \\
\downarrow \text { MHC-II on monocytes; anergy in infiltrating } \\
\text { T-cells; } \downarrow \text { TNF } \alpha \text { \& IFN- } \gamma \text {; Polarizes TAM } \\
\text { towards M2 phenotype }\end{array}$ & {$[60,62,63]$} \\
\hline 5. & TGF- 3 & $\begin{array}{l}\text { TAM and GFC (TGF- } \\
\text { B2) }\end{array}$ & $\begin{array}{l}\uparrow \text { immune suppression, } \uparrow \text { tumorigenesis, blocks } \\
\text { NK cells activity, } ₫ \text { T-cells, } \uparrow \text { Tregs, } \downarrow \text { IL- } 2 \text {, } \\
\pm N K G 2 D \text { on CD } 8+\text { T-cells, } \uparrow \text { CD133+; Polarises } \\
\text { TAM towards M2 phenotype }\end{array}$ & [64-66] \\
\hline 6. & CSF-1 & GBM microglia & $\begin{array}{l}\text { Polarises TAMs toward M2 phenotype; } \uparrow \text { TAM } \\
\text { infiltration; blocking } \downarrow \text { recurrence chances }\end{array}$ & {$[67,68]$} \\
\hline 7. & PGE2 & Microglia/TAMs & Transforms DCs into regulatory phenotype & [69] \\
\hline 8. & CD95 & Microglia/TAMs & $\begin{array}{l}\text { Stimulates AKT kinase; } ₫ \text { GSK } 3 ß \text {; Induce Tc cell } \\
\text { apoptosis. }\end{array}$ & {$[70]$} \\
\hline 10. & CD59 & GBM microglia & $\begin{array}{l}\text { Enhances immunosuppression, inhibits the } \\
\text { formation of MAC, prevents activation of the } \\
\text { complement pathway }\end{array}$ & {$[5]$} \\
\hline 11. & CD70 & GBM cells & $\begin{array}{l}\text { Mediates T-cell apoptosis through interaction } \\
\text { with CD } 27\end{array}$ & {$[52]$} \\
\hline 12. & $\begin{array}{l}\text { CD73 } \\
\text { (adenosine) }\end{array}$ & $\begin{array}{l}\text { GBM cells and Host } \\
\text { cells }\end{array}$ & $\begin{array}{l}\uparrow \text { invasiveness ( } \uparrow \mathrm{MMP} 9, \uparrow \mathrm{ECM} \text { degradation, } \\
\downarrow \mathrm{TIMP} 1) ; \uparrow \text { VEGF; } \uparrow \mathrm{MMP} 2 ; \uparrow \alpha \text {-dystroglycan; } \\
\uparrow \mathrm{AR}_{2 \mathrm{~B}} \text { AR signalling ( } \uparrow \text { Drug efflux, } \\
\uparrow C \text { hemoresistance) }\end{array}$ & [71] \\
\hline 13. & Factor $\mathrm{H}$ & GBM cells & $\begin{array}{l}\uparrow \text { cleavage of C3b to inactive iC } 3 b \text {; } \downarrow \text { deposition } \\
\text { of C } 5 b-9 ; \uparrow \text { immunosuppression }\end{array}$ & {$[5]$} \\
\hline
\end{tabular}




\begin{tabular}{|c|c|c|c|c|}
\hline 14. & $\begin{array}{l}\text { CFHR5 } \\
\text { (Complement } \\
\text { Factor H related } \\
\text { protein 5) }\end{array}$ & GBM cells & $\begin{array}{l} \pm \text { complement-mediated cell lysis; } ₫ \text { decay } \\
\text { acceleration of C } 3 \text { convertase; homologous to } \\
\text { FH; } \uparrow \text { immunosuppression. }\end{array}$ & [5] \\
\hline 15. & $\begin{array}{l}\text { C1-IA (C1- } \\
\text { inactivator) }\end{array}$ & GBM cells & $\begin{array}{l}\ddagger \text { complement system activation by binding to } \\
\mathrm{C} 1 \mathrm{~s} \text { and } \mathrm{C} 1 \mathrm{r} ; \uparrow \uparrow \text { immunosuppression }\end{array}$ & [72] \\
\hline 16. & CCL22 and CCL2 & GBM cells & Attracts Tregs by binding to CCR 4 & [73] \\
\hline 17. & PDL-1 & $\begin{array}{l}\text { Microglia cells, TAM } \\
\text { and GBM cells }\end{array}$ & $\begin{array}{l}\text { Suppress Tc cell functions and proliferation by } \\
\text { binding to PD-1; Production of Bregs. }\end{array}$ & {$[4,52,53]$} \\
\hline 18. & CTLA-4 (CD157) & GBM cells & $\begin{array}{l} \pm \text { naïve T-cell and memory T-cell activation; } \downarrow T_{h} \\
\text { cell activation; augments MDSC. }\end{array}$ & [74] \\
\hline 19. & MIC-1 & Microglia cells, TAM & Polarises TAM towards M2 phenotype & [75] \\
\hline 20. & S100B & GBM cells & $\begin{array}{l}₫ \text { pro-inflammatory cytokines by TAMs; } ₫ \\
\text { STAT3 pathway }\end{array}$ & [76] \\
\hline 21. & EGF & Microglia cells, TAM & $\begin{array}{l}\uparrow \text { tumour evasion and migration; } \uparrow \\
\text { phosphorylation of AKT to } \uparrow \text { MMP } 9\end{array}$ & {$[77,78]$} \\
\hline 22. & VEGF & Microglia cells, TAM & $\begin{array}{l}\uparrow \text { vascularisation around a tumour; } \downarrow \text { the ability } \\
\text { of TAM to infiltrate GBM; } \downarrow \text { innate immune } \\
\text { system. }\end{array}$ & {$[79,80]$} \\
\hline 23. & cmvIL-10 & Infected GBM cells & $\begin{array}{l}\ddagger \text { DC maturation and antigen presentation; } \\
\text { Impairs mononuclear cell proliferation; } \downarrow \\
\text { cytokine production; } \uparrow \text { TGF- } \beta \text { production, } \downarrow \\
\text { MHC expression; } \uparrow \text { PDL- } 1 \text { on tumours. }\end{array}$ & [81] \\
\hline 24. & FasL/CD95L & Astrocytes & Induces T-cell apoptosis & [70] \\
\hline
\end{tabular}

Immunosuppressive cytokines secreted by GBM cells do not have a high enough systemic concentration to justify the impairment of peripheral immune cell functions. Impairment in antigen presentation capabilities alongside compromised Tcell activation of the immune system has been observed even in peripheral lymphatic tissue, irrespective of the underlying cause of the vitiated cell-mediated immunity. This, in turn, exacerbates the challenges to immunotherapeutic efforts.

Several studies have shown that most Tregs originate in the thymus region, suggesting that there is probably a chemotactic attraction that drives Tregs of thymic origin near the tumour microenvironment [59, 82]. This is further strengthened by studies that suggest a role for an unidentified secretory molecule in Treg chemoattraction as blocking of CCR4, the receptor for CCL22 and CCL2 failed to abrogate Treg infiltration into GBM tumour mass [83, 84].

On the other hand, TAMs have a high expression of both CD11b and CD45 compared to microglia, which only display a high expression of CD11b, making it challenging for researchers to distinguish between the two types of cells as there is yet no distinguishable biological marker [85]. Recent studies have also shown that Myeloid Derived Suppressor Cells (MDSCs), which constitute the majority of the immunosuppressive force alongside TAM and cytokines in the vicinity of the tumour [86]. 


\subsection{Localisation based effect of B-cells in tumours}

The role of B-cells in immunity against cancer has been dubious as originally it was proved by Gordon et al. in 1982 that B-cells are necessary for early tumour antigen recognition and anti-tumour activity[87]. In 1989, Chow and Bennet hypothesised that B-cell recognition is necessary for the early detection of cancer by immunity [88]. However, the tide changed when seminal work by Schultz et al. showed that a B-cell-deficient mouse (muMT mice) does not display increased tumourigenesis compared to wild-type (WT) mice [89]. Over the past two decades, there have been many reports depicting the absence of B-cells in immunotherapy and focusing on T-cells for cancer-based immunity and cancer vaccines. However, some studies indicated that Bcells indeed are important, leading to the notion that muMT mice might present an exception due to different pathways or specific experimental factors. The GBM microenvironment is also responsible for the conversion of B-cells that infiltrate tumours to regulatory B-cells (Bregs), which act as tumour protection cells. Bregs are not as well defined as Tregs, but recent studies on glioblastoma revealed that B-cells with both tumour suppressing and tumour promoting functions were present in the patients. This has led researchers to hypothesise that B-cells might present dual function, depending on their localisation: pro-tumourigenic function in the tumour (Breg) vs anti-tumour function in the periphery [90]. This theory is further supported by the fact that intra-tumoural depletion of B-cells results in the improvement of animal survival but is almost similar to systemic depletion of B-cells, indicating that only B-cells that are invading the tumour cells are transforming into Bregs by expressing PDL-1 and CD155 on their surface [91]. In 2014, two different research works were published highlighting how glioma produces ADAM-10 and placental growth, which are then recognised by naïve B-cells, transforming them into Bregs, ultimately resulting in suppression of CD8+ T-cells [92, 93]. In the GBM microenvironment, there are tumour-derived exosomes which are extracellular vesicles with an endosomal origin. These micro-vesicles are believed to carry PDL-1 from MDSC to the surface of B-cells, making them partially responsible for the production of Bregs [4]. The mechanism of B-cell infiltration in glioblastoma is still unclear, but it is well established that an adaptive B-cell that invades as a naïve B-cell ends up as a Breg, quite similar to a cytotoxic T-cell [91].

3.Natural antibodies and their role in immunosurveillance and immunotherapy Antibodies are specialised glycoproteins that are secreted by immune cells to recognise the antigens and identify the immunogenic antigen. Antibodies are further classified based on their functional and structural organisation into five different classes, namely $\operatorname{IgM} \operatorname{IgG}, \operatorname{Ig} \mathrm{A}, \operatorname{IgD}$ and $\operatorname{IgE}$. $\operatorname{Ig} M$ is rather distinct from any other antibody class, because it is the first antibody to be secreted against an immunogenic antigen. Interestingly, $\operatorname{IgG}$ is the class-switched $\operatorname{IgM}$ endowed with the ability to generate long-term and efficacious immunogenic memory. However, based on antigen stimulation, antibodies can be divided into two distinct classes, namely natural antibodies (nAbs) and adaptive antibodies, the latter more commonly known as secretory antibodies (aAbs or sAbs) (Fig. 3).

Natural antibodies are defined as antibodies or immunoglobulins that are present in the immune system in the absence of antigen stimulation [43]. These antibodies are very different from the adaptive immune system in several ways. They are the main ones responsible for the regulation of $\mathrm{B}$ cell response, suppression of allergic response, protection from cancer, and clearance of apoptotic debris and tumours [94] (Fig. 3). They have a broader and more generalised response to infection 
when compared to adaptive B-cells. Although broader, the response is rather immediate and omnipresent thanks to the germline nature, a simple and primitive structure characterised by the lack of non-templated nucleotides, little to no hypermutation and a restricted repertoire[95-97].

NAbs are generally produced by specialised B-cells having surface expression as follows $\mathrm{CD}^{+/}$, IgM ${ }^{\text {high }}, \mathrm{CD} 19^{\text {high }}, \mathrm{B} 220^{\text {low }}, \mathrm{IgD}^{\text {high }}, \mathrm{CD} 23^{+}$and

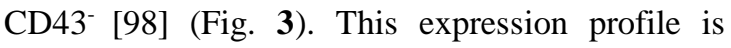
exactly the inverse of the one seen on normal Bcells, also known as adaptive B-cells (Fig. 3). The production of CD5 on the surface of T-cells was thought to be its distinct feature until it was recently found that some B-cell receptors are linked to natural IgM production, rendering them a specific subclass. Due to the earlier origin of NAb-producing B-cells, they are termed as B1 cells and the ones secreting adaptive Igs are termed as B2 cells; based on the presence or absence of CD5 receptor, B1 cells are further subclassified into B1a (CD5+) and B1b (CD5-) [99-101] (Fig. 3). It is postulated that B1a cells are produced during foetal development and are thereby maintained by self-renewal after the age of 3-6 weeks (neonatal development) [102]. Some studies showed that the expression of Lin $28 \mathrm{~b}$ induces a regulatory network of transcriptional regulators that support the development of B1a cells [103]. In the same study, it was stated that the Arid3a transcription factor is a key target of Let-7, whose ectopic expression is sufficient to induce B1 development in adult pro-B-cells and whose silencing by knockdown blocks B1 development in foetal pro-B-cells [103]. In the 1970s, studies demonstrated that antibody-producing cells specific for phosphorylcholine encoded by the T15 idiotype, later found to be expressed nearly exclusively by B1a cells, did not appear in the spleen and bone marrow until about one week after birth and were absent from the foetal liver [104].

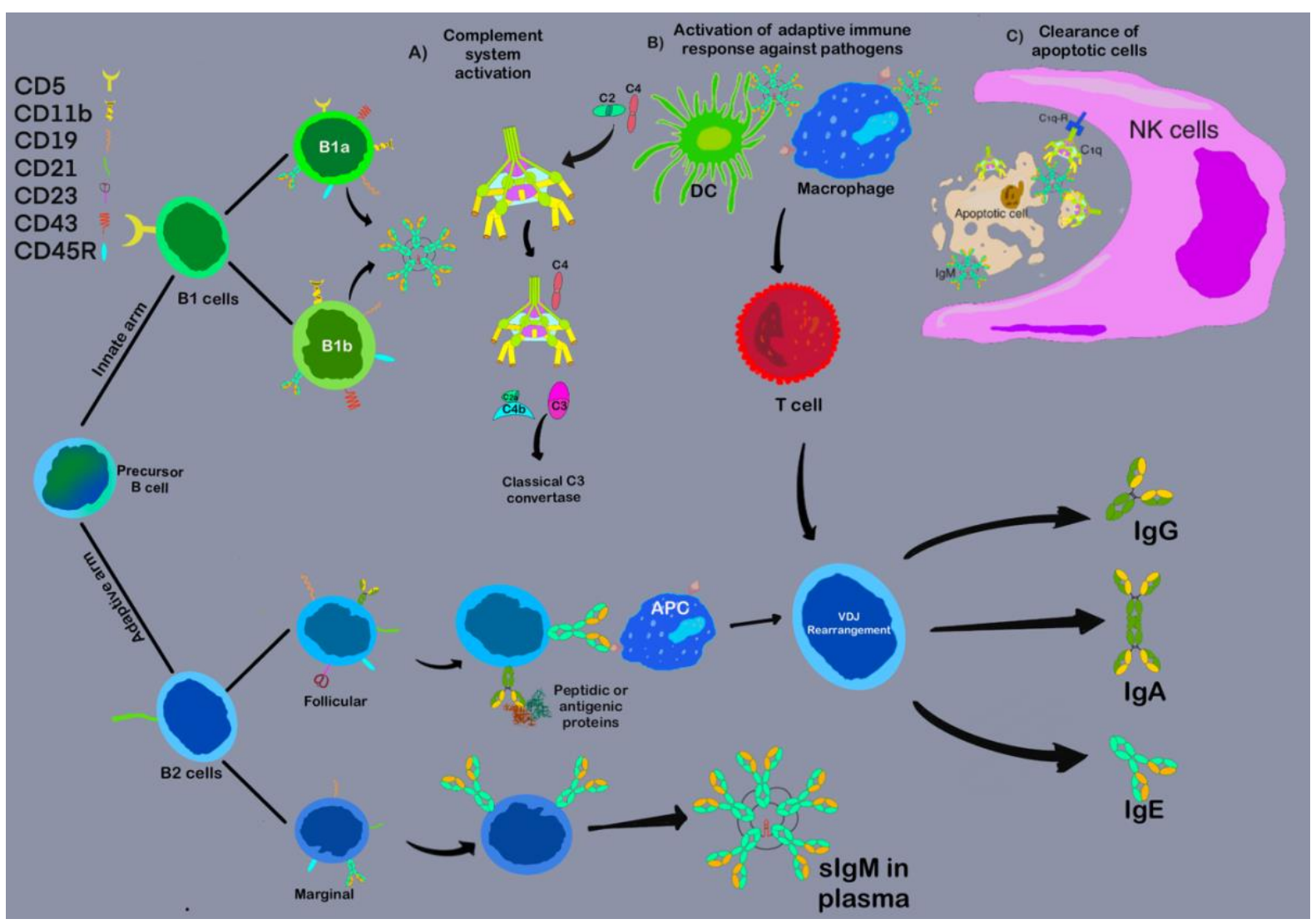


Figure 3. A composite figure summarising the molecular organisation of natural antibodies and their connection to other branches of immunity. The three major roles of natural $\operatorname{IgM}(\mathrm{nIgM})$ in the human body: A) Neutralising of pathogen and activation of the classical complement system. B) Activating a suitable immune response by polarising T-cells and triggering B-cell isotype class switch to activate the memory response. C) Clearance of apoptotic, cancerous cells along with cellular debris.

Natural $\operatorname{IgM}$ antibodies are germline-coded by specific germline families and not affinity matured via somatic mutations like adaptive natural antibodies. Brezinschek et al. demonstrated that the majority of monoclonal natural antibodies had germline-encoded VH and VL regions, and almost $80 \%$ of antibodies contained overexpressed DP47 and DP49 germline genes belonging to the VH3 family [105]. Similar to genetic restriction in the $\mathrm{VH}$ domain, it was reported that $90 \%$ of monoclonal $\mathrm{nAb}$ obtained from patients incorporated $\kappa$-light chains, giving them a $97.2 \%$ and $100 \%$ degree of identity when compared to the most homologous germline genes [105]. The high homology between germline genes and the $\mathrm{VH}$ and VL region of $\mathrm{nAbs}$ obtained from cancer patients and healthy individuals, together with the fact that these Abs have a lower incidence of silent mutations (R/S ratio), indicate very transparently that these Abs are germline-coded [106].

Atif et al. have shown that a healthy immune system is required for the recognition of neoantigenexpressing cells [107]. They further demonstrated that a diverse polyclonal IgM, but not IgG, repertoire is required for the rejection of neoantigen cells. In addition, they suggested that natural $\operatorname{IgM}$ includes specificities able to recognise neoantigenexpressing cells, and IgM is required to initiate the immune response against neoantigen-expressing cells, as all other cell types, APC subtypes and CD4 and CD8 lymphocytes, are present in IghelMD4 mice, yet they failed to generate any response against the neoantigen-expressing cells [107].

Moreover, natural IgM is a key player in immune complex formation, and several ex vivo studies include natural IgM binding on tumours in immunohistochemistry sections and tumour lysates in Western blots. The common hypothesis proposed by various scientists is that cellular immune complex formation, initiated by natural IgMs, i.e., antigen-antibody complexes, is likely to play a critical role during the early recognition and elimination phase of precancerous cells [106-110].

Earlier studies also show that IgM has a very high affinity $(10 \mathrm{nM})$ for TOSO/FAIM3, a regulator of Fas-induced apoptosis, thereby indicating a role of TOSO in immune surveillance through internalisation of IgM-bound immune complexes that contribute to B-cell activation [111]. Recent studies have also indicated that mice with nIgMdeficit genes produced more auto-antibodies ( $\mathrm{IgG}$ and $\operatorname{Ig} \mathrm{A}$ ) than mice with normal nIgM production $[112,113]$. It is evident that one of the roles of natural $\operatorname{IgM}$ antibodies includes the targeting of altered self-antigens or neo-epitopes on dying cells for targeted removal, thereby maintaining tissue homeostasis [107, 114].

One such antigen recognised by natural IgMs to facilitate the removal of apoptotic or dying cells is phosphorylcholine, which is also present on the cell wall of many parasites and microbes [115, 116], providing the first line of defence against pathogens. Carbohydrates, phospholipids, lipopolysaccharides, low-density lipoproteins, single-and doublestranded DNA are other antigen specificities known to be recognised by natural IgM antibodies, thus making it a very effective force against the tumour cells $[106,114]$. It has been demonstrated that one of the key features of a tumour cell is the presence of altered glycopeptides or carbohydrate antigens on its surface, which in a healthy person are recognised by the innate immune system (nIgM, NK cells, 
dendritic cells), leading in turn to apoptosis of these cells $[114,117]$. Recently, Becker et al. discussed the role of Mannitou $\operatorname{IgM}$; a murine $\operatorname{IgM}$ raised against a $130-\mathrm{kDa}$ glycoprotein obtained from the leech CNS, in reducing the tumourigenesis of GBM when glioblastoma cell lines were grown in the presence of IgM antibodies [117]. AHNAK, a giant 629-kDa molecule, was found out to be paucimannosylated and recognised as the major tumour suppressor protein identified in the presence of Mannitou IgM as it leads to a reduction in migration, invasion and proliferation of GBM. However, it is still unknown how IgM upregulated AHNAK production, even though this discovery has put IgM on the map as yet again a potent anti-tumour molecule [117].

\section{Why IgM and not IgG?}

Chemotherapy was introduced in the repertory of therapeutic interventions in the 1940s. Initially, chemotherapy relied on toxic chemicals (molecules) that could kill the cancer cells. The dawn of targeted therapy or modern chemotherapy arguably began shaping in the late $20^{\text {th }}$ century. Over $60 \mathrm{mAb}$-based drugs are currently approved and distributed with worldwide revenue of $\$ 138$ - \$163 billion in 2019 and with a Compound Annual Growth Rate (CAGR) of $12.0 \%$ through $2022[118,119]$. There is a great potential in the market for mAbs both regarding drug delivery and immunotherapy. The aforementioned claim is demonstrated by PAT-SM6, a GRP78targeting monoclonal antibody that is used for the treatment of melanoma $[120,121]$ and IGM-2323 for the shrinkage of non-hodgkin lymphoma as it contains nine high-affinity binding domains for CD20 and one binding domain for CD3 [122]. IGM2323 is able to eliminate CD20-positive lymphoma cells by engaging T-cells and lymphoma cells, leading to T-cell dependent cellular cytotoxicity. Additionally, IGM-2323 is also able to eliminate lymphoma cells by recruiting complement to the surface of lymphoma cells, leading to complementdependent cytotoxicity. In a study conducted in 2014, it was reported that novel IgM-based Antibody-Drug Conjugates (ADC) could be used to selectively kill chronic lymphocytic leukaemia cells. IgM-based ADC binds to the Fc $\mu$ receptor, which leads to rapid internalisation and intracellular cytotoxic payload delivery, making $\operatorname{IgM}$ a more suitable drug carrier than IgG counterparts as they lack the above-mentioned activity [123]. Although there are many non-IgG based drugs available in the market and clinical trials, IgG predominates [124]. This can mainly be attributed to the fact that IgGs were the first $\mathrm{mAb}$ to be cloned. IgG generally exists as a monomer, with a molecular weight of around $150 \mathrm{kDa}$, making it a relatively small immunoglobulin. IgG can trigger multiple pathways by interacting with the FcyR, found on many immune cells to mediate functions like AntibodyDependent Cellular Cytotoxicity (ADCC) and to some extent trigger Complement-Dependent Cytotoxicity (CDC) [125]. Due to this property, they can easily travel in the bloodstream and diffuse to the target tissue, rendering high potency as a therapeutic molecule.

To date, IgM has been largely left out from the biopharmaceutical market or ignored as their structural characteristics were difficult to understand, had a lower affinity when compared to IgG, showed cross-reactivity and most importantly, had a pentamer structure [126]. In the early $21 \mathrm{st}$ century and following the discovery of natural antibodies, the tide took a turn as carbohydrates were involved as a new class of antigen separate from peptide-based antigens evolved. Carbohydrates or glycoepitopes are now believed to be the main epitopes recognised by the natural immune system on tumour cells and are termed as Tumour Associated Antigen (TAA) or Tumour 
associated Carbohydrate Antigen (TACA) [127]. Many studies revealed that glyco-epitopes are very different from traditional peptide-based epitopes as they share a wide array of structural homologies, making them prone to cross-react extensively, and thereby suitable ligands for highly valent nIgMs [110, 114]. A major advantage of IgM comes from their multimeric nature: recent electron microscopy imaging showed that IgM is a mushroom / turtleshaped molecule with a central dome constructed by the Fc region of each chain from which the antigenbinding fragments (Fab) arms radiate outwards, flexible enough to make a move freely [128]. This unique feature of $\operatorname{IgM}$ (both nIgM and sIgM) makes them a potent activator of the complement system as they can easily and strongly bind to $\mathrm{C} 1 \mathrm{q}$ in a $1: 1$ or 1:2 ratio to trigger the ADCC pathway. $\mathrm{nIgM}$ along while being a potent complement system activator, can also detect neoantigens and react to self-antigens (carbohydrate residues on the surface of cells), giving them a natural ability to apoptosize tumour cells thanks to the features mentioned above in combination with a limited gene pool [107]. Certain studies also show that IgM can bind very tightly to the glycan antigens with affinities in the sub- nanomolar range, making them better binders to glycan epitopes when compared to IgGs $[129,130]$. Furthermore, despite their colossal size, IgM are able to invade tumour cells successfully, making them good candidates as therapeutic or diagnostic molecules [106].

A recent study by Samsudin et al. suggested that even two IgM molecules can act differently based on antigen recognition [131]. Their predictive model showed that Pertuzumab IgM displayed the best binding results as it was able to utilise all of its antigen-binding sites to bind to multiple HER receptors, while Trastuzumab IgM failed to do so due to steric hindrance, lending it a lower effective rate compared to their IgG counterparts [131]. This is a reminder that despite the advantages of $\operatorname{IgMs}$ over IgG, a suitable understanding of antigenantibody interaction as well as a suitable mode of delivery is required to achieve maximum efficiency. IgM effectiveness has been proven recently in targeting different types of cancers like melanoma, stomach carcinoma, breast cancer, lung cancer, and many more based on the effective recognition of glycan epitopes [106, 107, 110, 132].

Table 3: List of monoclonal IgM antibodies that have undergone clinical trials.

\begin{tabular}{|c|c|c|c|c|c|}
\hline Antibody & Antigen & Production cell & Disease targeted & $\begin{array}{c}\text { Clinical } \\
\text { trial }\end{array}$ & Reference \\
\hline $\begin{array}{l}\text { XMMEN- } \\
\text { 0E5 }\end{array}$ & J5 Lipid A & $\begin{array}{c}\text { Hybridoma with mouse } \\
\text { myeloma }\end{array}$ & Sepsis & Phase 3 & [133] \\
\hline HA-1A & J5 Lipid A & $\begin{array}{l}\text { Heteromyeloma with } \\
\text { lymphoma spleen cells }\end{array}$ & Sepsis & Phase 1 & [134] \\
\hline MAB-T88 & LPS & $\begin{array}{l}\text { Hybridoma with mouse } \\
\text { myeloma }\end{array}$ & Neutropenia & Phase 1 & [135] \\
\hline $\begin{array}{l}\text { Fanolesomab- } \\
\text { Tc99 }\end{array}$ & $\begin{array}{c}\text { CD15 } \\
\text { (carbohydrate) }\end{array}$ & $\begin{array}{l}\text { Hybridoma with mouse } \\
\text { myeloma }\end{array}$ & $\begin{array}{l}\text { Appendicitis } \\
\text { diagnosis }\end{array}$ & Phase 3 & [136] \\
\hline PAT-SC1 & $\begin{array}{l}\text { CD55 (glycan } \\
\text { isoform) }\end{array}$ & $\begin{array}{l}\text { Recombinant production } \\
\text { Per.C6 cells }\end{array}$ & Gastric cancer & Phase 1 & [137] \\
\hline $\mathrm{mAb} 216$ & $\begin{array}{c}\text { CDIM } \\
\text { (carbohydrate) }\end{array}$ & $\begin{array}{l}\text { Heteromyeloma with } \\
\text { lymphoma spleen cells }\end{array}$ & B-lineage ALL & Phase 1 & [138] \\
\hline PAT-SM6 & $\begin{array}{c}\text { GRP78 (O- } \\
\text { linked glycan) }\end{array}$ & $\begin{array}{l}\text { Recombinant production } \\
\text { Per.C6 cells }\end{array}$ & $\begin{array}{l}\text { Multiple } \\
\text { myeloma }\end{array}$ & Phase 1 & {$[121]$} \\
\hline L612 & $\begin{array}{l}\text { Ganglioside } \\
\text { GM3 }\end{array}$ & $\begin{array}{c}\text { EBV-transformed patient B } \\
\text { cells }\end{array}$ & Melanoma & Phase 1 & [139] \\
\hline
\end{tabular}




\begin{tabular}{|c|c|c|c|c|c|}
\hline MORAb-028 & $\begin{array}{c}\text { Ganglioside } \\
\text { GD2 }\end{array}$ & $\begin{array}{c}\text { Hybridoma with } \\
\text { human/mouse myeloma }\end{array}$ & Melanoma & $\begin{array}{c}\text { Phase } \\
1 / 2 \mathrm{a}\end{array}$ & {$[140]$} \\
\hline rHIgM22 & $\begin{array}{c}\text { CNS myelin } \\
\text { proteolipid }\end{array}$ & Recombinant & $\begin{array}{c}\text { Multiple } \\
\text { sclerosis/neuronal } \\
\text { degeneration } \\
\text { diseases }\end{array}$ & Phase 1 & {$[141]$} \\
\hline
\end{tabular}

Table 3 illustrates $\operatorname{IgM} \mathrm{mAbs}$ that have been approved for clinical trials for their use as therapeutic agents. It is important to note that these IgM antibodies were well tolerated in the patients. Their antigens comprise lipopolysaccharides (LPS) and its component core structure lipid A, gangliosides, proteolipids, and glycans (Table 3), which are generally poorly immunogenic because of their non-protein nature, which makes it difficult to target them by the commonly used IgGs [142]. However, their repeated or polymeric antigenic motifs embedded in cell membranes allows the pentameric or hexameric $\operatorname{IgM}$ to bind in a multivalent fashion. Due to their avidity and polyreactivity by presenting 10 or 12 paratopes simultaneously to their antigens, IgM antibodies mAbs display a striking advantage over their $\operatorname{IgG}$ counterparts.

Apart from the detection of epitopes proper to cancer cells, the immune response can be boosted for nIgM.

Kaveri et al. summarise several ways to induce and boost nIgM levels, like by exogenous administration of IL-18, the use of synthetic peptides that mimic poorly immunogenic non-protein antigens, and idiotypic vaccination strategies that boost $\operatorname{IgM}$ and IgG levels against NeuGcGM3 gangliosides antigen [111]. IL-18 is a strongly pro-inflammatory cytokine that has the ability to regulate the production of nAbs by inducing the expansion of the innate-type marginal zone B-cells subset [143] and the B1b cells [144]. These techniques can be investigated further to look into their potential as anti-cancer immunotherapy to be given alongside standard chemotherapy.
Studies have demonstrated that nIgM, more specifically HIgM12, has the potential to protect and remyelinate neurons, giving them a protecting role in the brain [144, 145]. It also established that $\operatorname{IgM}$ could cross the Blood Brain Barrier (BBB) intrinsically as nIgM doses were administered via intraperitoneal or intravenous routes in the murine models. The proposed mechanism of action of HIgM12 indicates that it binds GD1a and GT1b, complex gangliosides present in the plasma membrane of neurons. Gangliosides have a ceramide tail that anchors them to the plasma membrane while the external glycan moieties protrude out to act as a receptor for different kinds of ligands. HIgM12 probably clusters gangliosiderich membrane microdomains into larger complexes. Precisely, HIgM12 first binds to the neuronal membrane by colocalising with GM1 and cholesterol, thus segregating into the lipid-raft fraction and overriding myelin- and MAG-driven inhibition of neurite extension [145].

\section{Targeting GBM across the Brain Blood Barrier}

The major setback of detecting or treating GBM has always been its location, as it is most of the time protected by $\mathrm{BBB}$, which acts like a filtering membrane keeping most of the toxins and serum albumins away from the brain. It is a major limiting factor for mAb-based drugs and immunotherapy as only $0.1 \%$ to $0.6 \% \mathrm{mAb}$ is reported to enter the target site, thereby needing patients to take relatively very high doses of even the most potent mAbs (100 $\mathrm{mg} / \mathrm{kg}$ of body weight) [124]. There are several approaches tried by scientists over five decades to overcome this barrier ranging from physical to 
chemical disruption of BBB. Theoretically, the primary route of administration is to directly inject the therapeutic agent into the brain parenchyma or cerebrospinal fluid (CSF) (Fig. 4). This is predominantly used in experimental work and preclinical, but never in a clinical trial due to a higher risk of damage via the needle or of infection in the brain. Moreover, even if the drug is directly introduced into the brain/tumour site, it barely moves across the injection site due to the highly compact nature of brain tissues, making it a highly inefficient route of drug administration [146-148]. The effectiveness of the drug has been reported to reduce simultaneously when the drug is introduced via CSF due to the passage to the surrounding parenchymal tissue being diffusive in nature. This slow process is even more problematic when dealing with therapeutic molecules such as $\operatorname{IgM}$ or IgGs due to their sheer size and rapid removal via the glymphatic system [149-151].

During the 1980s, various methods such as osmotic (intracarotid mannitol) disruption were tried to temporarily remove or disrupt the $\mathrm{BBB}$ via endothelial shrinkage, resulting in the opening of tight junctions [152, 153] (Fig. 4). These methods were largely effective but never reached clinical trials as nontargeted disruption led to the entry of many unwanted and toxic serum proteins and inflammatory molecules that are generally filtered out due to the presence of BBB [154]. Similar is the case of targeted methods like the use of bradykinin and analogues, as they succeeded in preclinical trials but were never put forward for clinical trials probably due to a short active span to prevent inflow of toxic serum proteins $[155,156]$. The most efficient method to disrupt the BBB and allow the influx of monoclonal therapeutic antibodies comes in the form of high-power focused ultrasound, but it suffers from a major disadvantage such as damage and distortion of neighbouring tissues [157-159]
(Fig. 4). In order to surpass this obstacle, microbubbles are introduced alongside with lowfrequency ultrasound, resulting in microbubble cavitation and oscillation, leading to disruption of $\mathrm{BBB}$ in the local vicinity. This approach is one of the most promising methods to deliver IgM-based nanobodies, but the studies lack the long-term consequences and the degree of penetration that can be achieved based on this method as the efflux transport mechanism remains active [157, 160, 161] (Fig. 4). Moreover, the contraction and expansion of air bubbles create thermal energy, which, in turn, can physically damage cells, causing cell death [162].

While most of the above-mentioned methods highlight the disruption of $\mathrm{BBB}$ to increase the uptake of therapeutic molecules in the BBB, an alternative practice is to improve the uptake of the therapeutic or diagnostic molecules by modifying the agent itself. This is mainly achieved by making the carrier molecule more lipophilic and the drug more receptable in the brain, but at the cost of increased off-target effects, as a result of membrane permeability [163, 164] (Fig. 4).

Nanocarriers were introduced that were made from diverse structures such as liposomes, phospholipids, polymer-based particles, and many other molecules with the common goal to be loaded with the drug/therapeutic agent and to deliver it across the BBB into the brain. These special particles are termed as nanoparticles [165]. Once the nanoparticle reaches the brain, the change in chemical surroundings like $\mathrm{pH}$ or exclusive molecules present in the tumour microenvironment destabilises the nanocarrier, resulting in effective drug delivery [166] (Fig. 4). However, the main problem in using nanoparticles in the brain is that they tend to release a small amount of drug at nonspecific sites en-route to the target site and all across the brain, making them less efficient. In order to overcome this 
problem, molecular tags like transferrin, EGFPEGF1 fusion protein, metalloprotease-2 are used as they specifically bind to receptors present on GBM cells like TfR-1 bind transferrin, while tumourexpressed chloride channels bind cholera toxin [11, 78, 167]. These tag-infused nanoparticles hold significant promise for drug delivery but still do not answer the problem related to the transfer of large molecules like IgM or other therapeutic antibodies [168]. Apart from this, only a few of them are undergoing clinical trials for GBM, and none of them are close to being approved [169-171].

In order to deliver protein macromolecules like therapeutic antibodies, a process known as receptormediated transcytosis is used. It is a direct molecular tagging of the therapeutic molecule itself and is considered as the best possible solution as they are recognised by endothelial transporters [171, 172]. Alongside, many alternative approaches have been developed for effective transfer of therapeutic antibodies across BBB, such as making Fc domains of antibodies specific against the endothelial receptors so that they get accepted more easily, [173] or modifying an Abs with one Fab arm recognising an endothelial transporter while the other Fab arm is specific towards the targeted antigen[174, 175] (Fig. 4). Some studies also included linking an endothelial transporter domain onto the light and heavy chains [176]. In a recent study conducted by Galstyan et al., it was demonstrated that by conjugating already existing anti-CTLA-4 and anti-PD-1 IgG antibodies with a natural biopolymer scaffold-like poly $\beta$-L-malic acid or 3-(2-pyridyldithio) propionate (PDP) significantly increased its absorption across BBB [176] (Fig. 4).

Nevertheless, despite substantial recent advances, it is still challenging to deliver precisely a relevant dose of therapeutic antibodies to the human brain, mainly due to the fact that $\mathrm{BBB}$ is such a selective and complex barrier that its disruption can cause more harm than good to the patient in the long-term. On the other hand, molecules like IgM, which are already in the nanomolar range, can be used to deliver the drug or in diagnostics by conjugating it with a fluorescent marker like 5-ALU for early diagnosis of GBM.

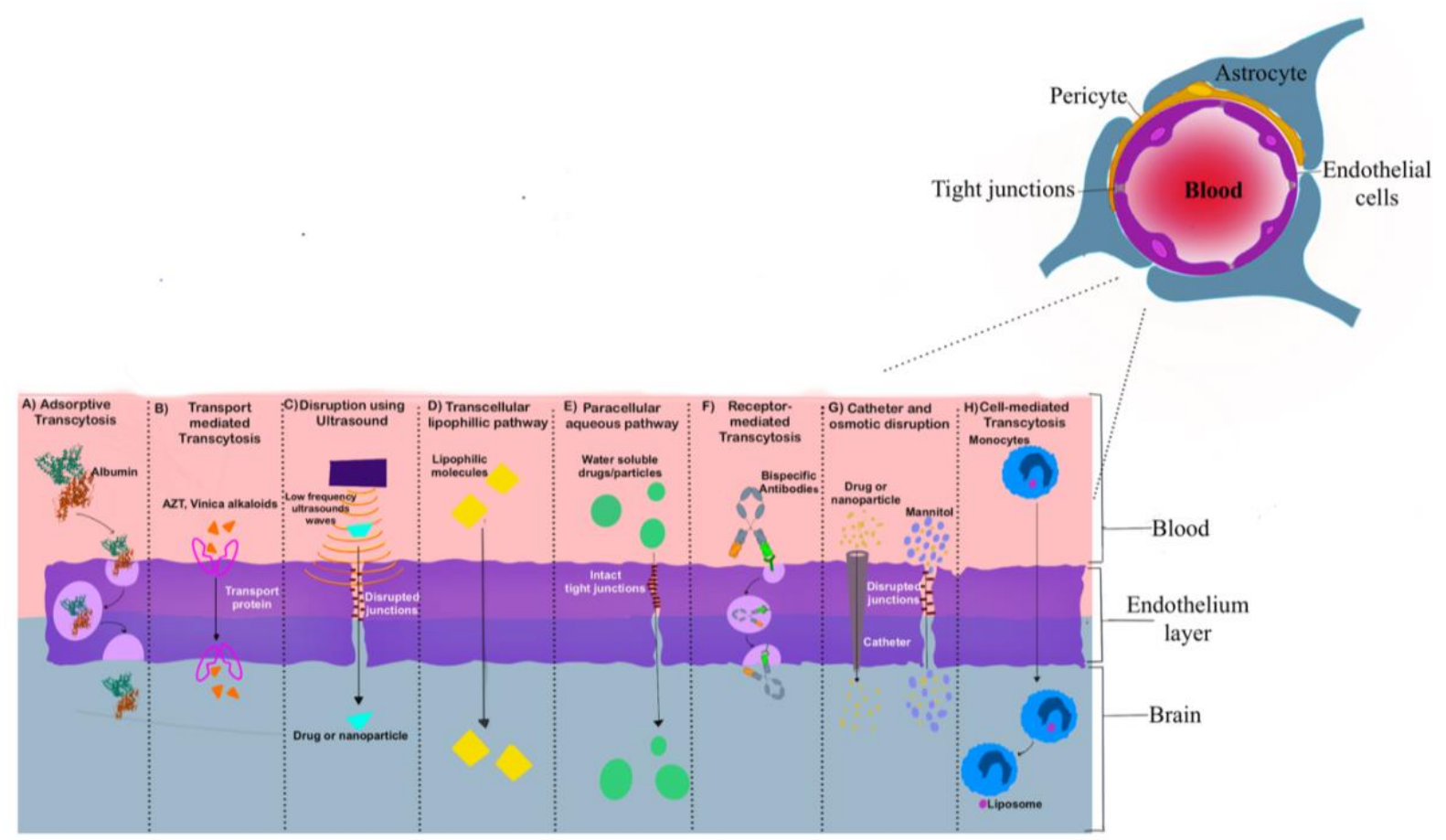


Figure 4. Different pathways and interventions to cross the brain-blood barrier. A) Adsorptive transcytosis is a direct approach where molecules/proteins like albumin are directly transported across the BBB via vesicles. B) Transport mediated transcytosis is used by many drugs like AZT, Vinca alkaloids, where they interact with transport proteins which specifically transfer selected proteins across the BBB. C) Low-frequency ultrasound can temporarily disrupt the tight junctions, thereby allowing the drug to pass across the BBB. D) Lipophilic molecules can directly cross the BBB. E) Water-soluble molecules/drugs pass through tight junctions to cross the BBB without disrupting the barrier itself via a paracellular aqueous pathway. F) Bispecific antibodies have two armsone for recognising the receptor present on the endothelium layer of $\mathrm{BBB}$ and the other one to trigger a suitable therapeutic response against cancer. As such, it uses a receptor-mediated pathway to move across the BBB. G) Invasive methods to disrupt BBB can be risky as it involves semipermanent disruption of the BBB using mannitol, a linear mannose saccharide, and directly using a catheter to deliver the drug or nanoparticles to the brain. $\mathrm{H}$ ) Some cells like monocytes have the ability to cross the BBB using cell-mediated transcytosis.

\section{CONCLUSION}

Upon surveyal of the literature, we can conclude that IgM antibodies hold the potential to be used as potent anti-cancer therapeutics in the coming years. It has already been proven that natural $\operatorname{IgM}$ antibodies have a protective role against cancer, especially glioblastoma. With the gradual improvement in drug delivery systems and a better understanding of the biochemical and immunological interactions, we should be able to better target GBM cancer cells across the BBB in the near future. There are currently many IgM-based drugs in the pipeline, but there is a need to understand the interactions of IgMs better, as explained by Samsudin et al. [115], to gain a significant improvement in the survival span of the patients. Current knowledge on the treatment of GBM by targeted therapy is still limited; hence, further research on the role of IgM in GBM is warranted.

\section{AUTHORS' CONTRIBUTION}

The authors contributed to data acquisition, analysis, and manuscript preparation. The first author designed the review and prepared the initial review. The co-authors provided their expertise and provided additional data and suggestions to improve the quality of the article. Finally, the corresponding author critically reviewed the article and made necessary amendments to prepare the article for publication.

\section{FUNDING}

The authors acknowledge financial support through the Programme for EArly-stage Researchers in Lille (PEARL), under the auspices of the European Union Horizon 2020 research and innovation programme, project "ATACA" with Marie Sklodowska-Curie agreement No. 847568. PEARL is coordinated by the Foundation I-SITE ULNE and implemented at the Centre National de la Recherche Scientific (CNRS).

\section{ACKNOWLEDGEMENTS}

The authors express their gratitude to the University of Lille for granting MOBLILEX mobility to Lille for Shubham Semwal. Furthermore, we are grateful to Dr. Vibha Gupta at the Jaypee Institute of Information Technology (JIIT) in Noida, India, for elaborate discussions on the topic.

\section{CONSENT FOR PUBLICATION}

Declared none.

\section{CONFLICT OF INTEREST}

The authors declare no conflict of interest, financial or otherwise 
[1] WHO | IARC - International Agency for Research on Cancer 2020 [Available from: https://gco.iarc.fr/today/online-analysismap? $v=2020 \&$ mode $=$ population \&mode_p opulation $=$ continents $\&$ population $=900 \& p$ opulations $=900 \&$ key $=$ asr $\&$ se $x=0 \&$ cancer $=39 \&$ type $=0 \&$ statistic $=5 \&$ prevalence $=0 \&$ population group $=0 \&$ ages group $\% 5 \mathrm{~B} \% 5$ $\mathrm{D}=0$ \&ages group $\% 5 \mathrm{~B} \% 5 \mathrm{D}=17 \& \mathrm{nb}$ item s=10\&group cancer $=1 \&$ include $n$ msc $=1$ \&include nmsc other $=1 \&$ projection $=$ natu ral-

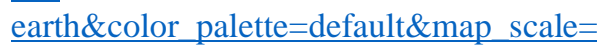
quantile\&map nb colors $=5 \&$ continent $=0$ \&show ranking $=0 \&$ rotate $=\% 255 \mathrm{~B} 10 \% 25$ 2C0\%255D.

[2] Hernandez-Pedro NY, Rangel-Lopez E, Vargas Felix G, Pineda B, Sotelo J. An update in the use of antibodies to treat glioblastoma multiforme. Autoimmune Dis. 2013;2013:716813.

[3] Ohgaki H, Kleihues P. Genetic pathways to primary and secondary glioblastoma. Am J Pathol. 2007;170(5):1445-53.

[4] Chen G, Huang AC, Zhang W, Zhang G, $\mathrm{Wu} \mathrm{M}, \mathrm{Xu} \mathrm{W}$, et al. Exosomal PD-L1 contributes to immunosuppression and is associated with anti-PD-1 response. Nature. 2018;560(7718):382-6.

[5] Junnikkala S, Jokiranta TS, Friese MA, Jarva H, Zipfel PF, Meri S. Exceptional resistance of human $\mathrm{H} 2$ glioblastoma cells to complement-mediated killing by expression and utilization of factor $\mathrm{H}$ and factor H-like protein 1. J Immunol. 2000;164(11):6075-81.

[6] Brown TJ, Brennan MC, Li M, Church EW, Brandmeir NJ, Rakszawski KL, et al. Association of the Extent of Resection With Survival in Glioblastoma: A Systematic Review and Meta-analysis. JAMA Oncol. 2016;2(11):1460-9.

[7] Noorbakhsh A, Tang JA, Marcus LP, McCutcheon B, Gonda DD, Schallhorn CS, et al. Gross-total resection outcomes in an elderly population with glioblastoma: a SEER-based analysis. J Neurosurg. 2014;120(1):31-9.

[8] Hadjipanayis CG, Stummer W. 5-ALA and FDA approval for glioma surgery. J Neurooncol. 2019;141(3):479-86.

[9] Vanya Bogoeva LP, Julie Bouckaert, Anna Yordanova, Ivan Ivanov, Régis Vanderesse, Céline Frochot. Dual function of lectins - new perspectives in targeted photodynamic therapy. Journal of Porphyrins and Phthalocyanines. 2019;23(12):1241-50.
[10] Stummer W, Pichlmeier U, Meinel T, Wiestler OD, Zanella F, Reulen HJ, et al. Fluorescence-guided surgery with 5aminolevulinic acid for resection of malignant glioma: a randomised controlled multicentre phase III trial. Lancet Oncol. 2006;7(5):392-401.

[11] Fang C, Wang K, Stephen ZR, Mu Q, Kievit FM, Chiu DT, et al. Temozolomide nanoparticles for targeted glioblastoma therapy. ACS Appl Mater Interfaces. 2015;7(12):6674-82.

[12] Stupp R, Mason WP, van den Bent MJ, Weller M, Fisher B, Taphoorn MJ, et al. Radiotherapy plus concomitant and adjuvant temozolomide for glioblastoma. N Engl J Med. 2005;352(10):987-96.

[13] Fabian D, Guillermo Prieto Eibl MDP, Alnahhas I, Sebastian N, Giglio P, Puduvalli V, et al. Treatment of Glioblastoma (GBM) with the Addition of Tumor-Treating Fields (TTF): A Review. Cancers (Basel). 2019;11(2).

[14] Kirson ED, Dbaly V, Tovarys F, Vymazal J, Soustiel JF, Itzhaki A, et al. Alternating electric fields arrest cell proliferation in animal tumor models and human brain tumors. Proc Natl Acad Sci U S A. 2007;104(24):10152-7.

[15] Taphoorn MJB, Dirven L, Kanner AA, Lavy-Shahaf G, Weinberg U, Taillibert S, et al. Influence of Treatment With TumorTreating Fields on Health-Related Quality of Life of Patients With Newly Diagnosed Glioblastoma: A Secondary Analysis of a Randomized Clinical Trial. JAMA Oncol. 2018;4(4):495-504.

[16] AFINITOR [package insert on the Internet]. East Hanover: Novartis; 2009 [Internet]. Available from: https://www.accessdata.fda.gov/drugsatfda docs/label/2009/022334lbl.pdf.

[17] AFINITOR [package insert on the Internet]. East Hanover: Novartis; Revised 10/2010 [Internet]. Available from: https://www.accessdata.fda.gov/drugsatfda docs/label/2010/022334s6lbl.pdf.

[18] AFINITOR [package insert on the Internet]. East Hanover: Novartis; Revised 05/2011 [Internet]. Available from: https://www.accessdata.fda.gov/drugsatfda _docs/label/2011/022344s9s101bl.pdf.

[19] AFINITOR [package insert on the Internet]. East Hanover: Novartis; Revised 07/2012 [Internet]. Available from: https://www.accessdata.fda.gov/drugsatfda docs/label/2012/022334s016lbl.pdf. 
[20] Avastin (bevacizumab) Information [Internet]. U.S. Food and Drug Administration. 2011. Available from: https://www.fda.gov/drugs/postmarketdrug-safety-information-patients-andproviders/avastin-bevacizumabinformation.

[21] AVASTIN [package insert on the Internet]. DNA Way

South San Francisco: Genentech; 2020 [Internet]. 2020. Available from: https://www.accessdata.fda.gov/drugsatfda docs/label/2020/125085s336lbl.pdf.

[22] BICNU [package insert on the Internet]. Hinjawadi, Pune: Emcure Pharmaceuticals Ltd.; 2017

[Internet]. Available from: https://www.accessdata.fda.gov/drugsatfda _docs/label/2017/017422s055lbl.pdf.

[23] Giladel Wafer [package insert on the Internet]. Woodcliff Lake: Eisai Inc.; 2018 [Internet]. Available from: https://www.accessdata.fda.gov/drugsatfda _docs/label/2018/020637s0291bl.pdf.

[24] lomustine capsule, gelatin coated [package insert on the Internet]. Sermoneta (LT): Corden Pharma Latina S.p.A.; 2013.

[25] TEMODAR (temozolomide) [package insert on the Internet]. Kenilworth: Schering Corporation; 1999 [Internet]. Available from: https://www.accessdata.fda.gov/drugsatfda docs/label/1999/21029lbl.pdf.

[26] TEMODAR (temozolomide) [package insert on the Internet]. Kenilworth: Schering Corporation; 2005 [Internet]. Available from: https://www.accessdata.fda.gov/drugsatfda docs/label/2005/021029s008lbl.pdf.

[27] Weber JS. Current perspectives on immunotherapy. Semin Oncol. 2014;41 Suppl 5:S14-29.

[28] Pan PC, Magge RS. Mechanisms of EGFR Resistance in Glioblastoma. Int $\mathbf{J}$ Mol Sci. 2020;21(22).

[29] Weller M, Butowski N, Tran DD, Recht LD, Lim M, Hirte H, et al. Rindopepimut with temozolomide for patients with newly diagnosed, EGFRvIII-expressing glioblastoma (ACT IV): a randomised, double-blind, international phase 3 trial. Lancet Oncol. 2017;18(10):1373-85.

[30] Gedeon PC, Choi BD, Sampson JH, Bigner DD. Rindopepimut: anti-EGFRvIII peptide vaccine, oncolytic. Drugs Future. 2013;38(3):147-55.

[31] Li G, Mitra S, Wong AJ. The epidermal growth factor variant III peptide vaccine for treatment of malignant gliomas. Neurosurg Clin N Am. 2010;21(1):87-93.
[32] Iwahara T, Fujimoto J, Wen D, Cupples R, Bucay N, Arakawa T, et al. Molecular characterization of ALK, a receptor tyrosine kinase expressed specifically in the nervous system. Oncogene. 1997;14(4):439-49.

[33] Wang L, Lui VWY. Emerging Roles of ALK in Immunity and Insights for Immunotherapy. Cancers (Basel). 2020;12(2).

[34] Allouche M. ALK is a novel dependence receptor: potential implications in development and cancer. Cell Cycle. 2007;6(13):1533-8.

[35] Kalamatianos T, Denekou D, Stranjalis G, Papadimitriou E. Anaplastic Lymphoma Kinase in Glioblastoma: Detection/Diagnostic Methods and Therapeutic Options. Recent Pat Anticancer Drug Discov. 2018;13(2):20923.

[36] FDA approves lorlatinib for second- or third-line treatment of ALK-positive metastatic NSCLC United state of America: Food and Drug Administration; 2018 [Available from: https://www.fda.gov/drugs/fda-approveslorlatinib-second-or-third-line-treatmentalk-positive-metastatic-nsclc.

[37] Lah TT, Novak M, Breznik B. Brain malignancies: Glioblastoma and brain metastases. Semin Cancer Biol. 2020;60:262-73.

[38] Search of: Anaplastic Lymphoma Kinase | brain - List Results - ClinicalTrials.gov [Internet]. NIH. [cited 21 Februrary 2021]. Available from: https://clinicaltrials.gov/ct2/results?recrs= \&cond=brain\&term=Anaplastic + Lympho $\underline{\text { ma }+ \text { Kinase }+\& c n t r y}=\&$ state $=\&$ city $=\&$ dist $=$.

[39] Binder DC, Ladomersky E, Lenzen A, Zhai L, Lauing KL, Otto-Meyer SD, et al. Lessons learned from rindopepimut treatment in patients with EGFRvIIIexpressing glioblastoma. Transl Cancer Res. 2018;7(Suppl 4):S510-S3.

[40] Bregeon D, Doetsch PW. Transcriptional mutagenesis: causes and involvement in tumour development. Nat Rev Cancer. 2011;11(3):218-27.

[41] Swann JB, Smyth MJ. Immune surveillance of tumors. J Clin Invest. 2007;117(5):1137-46.

[42] Ostrand-Rosenberg S. Immune surveillance: a balance between protumor and antitumor immunity. Curr Opin Genet Dev. 2008;18(1):11-8. 
[43] Ribatti D. The concept of immune surveillance against tumors. The first theories. Oncotarget. 2017;8(4):7175-80.

[44] Paul S, Lal G. The Molecular Mechanism of Natural Killer Cells Function and Its Importance in Cancer Immunotherapy. Front Immunol. 2017;8:1124.

[45] Hui E. Immune checkpoint inhibitors. J Cell Biol. 2019;218(3):740-1.

[46] Haanen JB, Cerundolo V. NKG2A, a New Kid on the Immune Checkpoint Block. Cell. 2018;175(7):1720-2.

[47] O'Donnell JS, Teng MWL, Smyth MJ. Cancer immunoediting and resistance to $\mathrm{T}$ cell-based immunotherapy. Nat Rev Clin Oncol. 2019;16(3):151-67.

[48] Li X, Shao C, Shi Y, Han W. Lessons learned from the blockade of immune checkpoints in cancer immunotherapy. $\mathbf{J}$ Hematol Oncol. 2018;11(1):31.

[49] Jackson C, Ruzevick J, Phallen J, Belcaid Z, Lim M. Challenges in immunotherapy presented by the glioblastoma multiforme microenvironment. Clin Dev Immunol. 2011;2011:732413.

[50] Rolle CE, Sengupta S, Lesniak MS. Challenges in clinical design of immunotherapy trials for malignant glioma. Neurosurg Clin N Am. 2010;21(1):201-14.

[51] Sharma V, Dixit D, Koul N, Mehta VS, Sen E. Ras regulates interleukin-1beta-induced HIF-1alpha transcriptional activity in glioblastoma. J Mol Med (Berl). 2011;89(2):123-36.

[52] Chahlavi A, Rayman P, Richmond AL, Biswas K, Zhang R, Vogelbaum M, et al. Glioblastomas induce T-lymphocyte death by two distinct pathways involving gangliosides and CD70. Cancer Res. 2005;65(12):5428-38.

[53] Razavi SM, Lee KE, Jin BE, Aujla PS, Gholamin S, Li G. Immune Evasion Strategies of Glioblastoma. Front Surg. 2016;3:11.

[54] Wu A, Wei J, Kong LY, Wang Y, Priebe $\mathrm{W}$, Qiao $\mathrm{W}$, et al. Glioma cancer stem cells induce immunosuppressive macrophages/microglia. Neuro Oncol. 2010;12(11):1113-25.

[55] Ostrand-Rosenberg S, Horn LA, Haile ST. The programmed death-1 immunesuppressive pathway: barrier to antitumor immunity. J Immunol. 2014;193(8):383541.

[56] Miska J, Lee-Chang C, Rashidi A, Muroski ME, Chang AL, Lopez-Rosas A, et al. HIF1alpha Is a Metabolic Switch between Glycolytic-Driven Migration and Oxidative Phosphorylation-Driven
Immunosuppression of Tregs in Glioblastoma. Cell Rep. 2019;27(1):22637 e4.

[57] Kostianovsky AM, Maier LM, Anderson RC, Bruce JN, Anderson DE. Astrocytic regulation of human monocytic/microglial activation. J Immunol. 2008;181(8):542532.

[58] Martinez FO, Gordon S. The M1 and M2 paradigm of macrophage activation: time for reassessment. F1000Prime Rep. 2014;6:13.

[59] Wainwright DA, Nigam P, Thaci B, Dey M, Lesniak MS. Recent developments on immunotherapy for brain cancer. Expert Opin Emerg Drugs. 2012;17(2):181-202.

[60] Yeung YT, McDonald KL, Grewal T, Munoz L. Interleukins in glioblastoma pathophysiology: implications for therapy. Br J Pharmacol. 2013;168(3):591-606.

[61] Tarassishin L, Lim J, Weatherly DB, Angeletti RH, Lee SC. Interleukin-1induced changes in the glioblastoma secretome suggest its role in tumor progression. J Proteomics. 2014;99:15268.

[62] Wang T, Niu G, Kortylewski M, Burdelya L, Shain K, Zhang S, et al. Regulation of the innate and adaptive immune responses by Stat- 3 signaling in tumor cells. Nat Med. 2004;10(1):48-54.

[63] Qi L, Yu H, Zhang Y, Zhao D, Lv P, Zhong $\mathrm{Y}$, et al. IL-10 secreted by M2 macrophage promoted tumorigenesis through interaction with JAK2 in glioma. Oncotarget. 2016;7(44):71673-85.

[64] Ye XZ, Xu SL, Xin YH, Yu SC, Ping YF, Chen L, et al. Tumor-associated microglia/macrophages enhance the invasion of glioma stem-like cells via TGFbeta1 signaling pathway. J Immunol. 2012;189(1):444-53.

[65] Fontana A, Bodmer S, Frei K, Malipiero U, Siepl C. Expression of TGF-beta 2 in human glioblastoma: a role in resistance to immune rejection? Ciba Found Symp. 1991;157:232-8; discussion 8-41.

[66] Matsushita K, Takenouchi T, Shimada H, Tomonaga T, Hayashi H, Shioya A, et al. Strong HLA-DR antigen expression on cancer cells relates to better prognosis of colorectal cancer patients: Possible involvement of c-myc suppression by interferon-gamma in situ. Cancer Sci. 2006;97(1):57-63.

[67] Stafford JH, Hirai T, Deng L, Chernikova $\mathrm{SB}$, Urata K, West BL, et al. Colony stimulating factor 1 receptor inhibition delays recurrence of glioblastoma after radiation by altering myeloid cell 
recruitment and polarization. Neuro Oncol. 2016;18(6):797-806.

[68] De I, Steffen MD, Clark PA, Patros CJ, Sokn E, Bishop SM, et al. CSF1 Overexpression Promotes High-Grade Glioma Formation without Impacting the Polarization Status of Glioma-Associated Microglia and Macrophages. Cancer Res. 2016;76(9):2552-60.

[69] Oliver LaO, Christophe and Vallette, Francois M. Prostaglandin E2 plays a major role in glioma resistance and progression. Translational Cancer Research. 2016;5.

[70] Blaes J, Thome CM, Pfenning PN, Rubmann P, Sahm F, Wick A, et al. Inhibition of CD95/CD95L (FAS/FASLG) Signaling with APG101 Prevents Invasion and Enhances Radiation Therapy for Glioblastoma. Mol Cancer Res. 2018;16(5):767-76.

[71] Yan A, Joachims ML, Thompson LF, Miller AD, Canoll PD, Bynoe MS. CD73 Promotes Glioblastoma Pathogenesis and Enhances Its Chemoresistance via A2B Adenosine Receptor Signaling. J Neurosci. 2019;39(22):4387-402.

[72] Fornvik K, Maddahi A, Persson O, Osther K, Salford LG, Nittby Redebrandt H. C1inactivator is upregulated in glioblastoma. PLoS One. 2017;12(9):e0183086.

[73] Zhou M, Bracci PM, McCoy LS, Hsuang G, Wiemels JL, Rice T, et al. Serum macrophage-derived chemokine/CCL22 levels are associated with glioma risk, CD4 $\mathrm{T}$ cell lymphopenia and survival time. Int $\mathrm{J}$ Cancer. 2015;137(4):826-36.

[74] Huang J, Liu F, Liu Z, Tang H, Wu H, Gong $\mathrm{Q}$, et al. Immune Checkpoint in Glioblastoma: Promising and Challenging. Front Pharmacol. 2017;8:242.

[75] Gregoire H, Roncali L, Rousseau A, Cherel M, Delneste Y, Jeannin P, et al. Targeting Tumor Associated Macrophages to Overcome Conventional Treatment Resistance in Glioblastoma. Front Pharmacol. 2020;11:368.

[76] Zhang L, Liu W, Alizadeh D, Zhao D, Farrukh O, Lin J, et al. S100B attenuates microglia activation in gliomas: possible role of STAT3 pathway. Glia. 2011;59(3):486-98.

[77] Chen XC, Wei XT, Guan JH, Shu H, Chen D. EGF stimulates glioblastoma metastasis by induction of matrix metalloproteinase-9 in an EGFR-dependent mechanism. Oncotarget. 2017;8(39):65969-82.

[78] Zhang B, Wang H, Liao Z, Wang Y, Hu Y, Yang J, et al. EGFP-EGF1-conjugated nanoparticles for targeting both neovascular and glioma cells in therapy of brain glioma. Biomaterials. 2014;35(13):4133-45.

[79] Turkowski K, Brandenburg S, Mueller A, Kremenetskaia I, Bungert AD, Blank A, et al. VEGF as a modulator of the innate immune response in glioblastoma. Glia. 2018;66(1):161-74.

[80] Souberan A, Brustlein S, Gouarne C, Chasson L, Tchoghandjian A, Malissen M, et al. Effects of VEGF blockade on the dynamics of the inflammatory landscape in glioblastoma-bearing mice.

Neuroinflammation. 2019;16(1):191.

[81] Abdelaziz MO, Ossmann S, Kaufmann AM, Leitner J, Steinberger P, Willimsky G, et al. Development of a Human Cytomegalovirus (HCMV)-Based Therapeutic Cancer Vaccine Uncovers a Previously Unsuspected Viral Block of MHC Class I Antigen Presentation. Front Immunol. 2019;10:1776.

[82] Jacobs JF, Idema AJ, Bol KF, Grotenhuis $\mathrm{JA}$, de Vries IJ, Wesseling $\mathrm{P}$, et al. Prognostic significance and mechanism of Treg infiltration in human brain tumors. $\mathbf{J}$ Neuroimmunol. 2010;225(1-2):195-9.

[83] Desbaillets I, Tada M, de Tribolet N, Diserens AC, Hamou MF, Van Meir EG. Human astrocytomas and glioblastomas express monocyte chemoattractant protein1 (MCP-1) in vivo and in vitro. Int $\mathbf{J}$ Cancer. 1994;58(2):240-7.

[84] Jordan JT, Sun W, Hussain SF, DeAngulo G, Prabhu SS, Heimberger AB. Preferential migration of regulatory $T$ cells mediated by glioma-secreted chemokines can be blocked with chemotherapy. Cancer Immunol Immunother. 2008;57(1):123-31.

[85] Ford AL, Goodsall AL, Hickey WF, Sedgwick JD. Normal adult ramified microglia separated from other central nervous system macrophages by flow cytometric sorting. Phenotypic differences defined and direct ex vivo antigen presentation to myelin basic proteinreactive $\mathrm{CD} 4+\mathrm{T}$ cells compared. $\mathrm{J}$ Immunol. 1995;154(9):4309-21.

[86] Ostrand-Rosenberg S, Fenselau C. Myeloid-Derived Suppressor Cells: Immune-Suppressive Cells That Impair Antitumor Immunity and Are Sculpted by Their Environment. J Immunol. 2018;200(2):422-31.

[87] Gordon J, Holden HT, Segal S, Feldman M. Anti-tumor immunity in B-lymphocytedeprived mice. III. Immunity to primary Moloney sarcoma virus-induced tumors. Int J Cancer. 1982;29(3):351-7. 
[88] Chow DA, Bennet RD. Low natural antibody and low in vivo tumor resistance, in xid-bearing B-cell deficient mice. J Immunol. 1989;142(10):3702-6.

[89] Schultz KR, Klarnet JP, Gieni RS, HayGlass KT, Greenberg PD. The role of $\mathrm{B}$ cells for in vivo $\mathrm{T}$ cell responses to a Friend virus-induced leukemia. Science. 1990;249(4971):921-3.

[90] Yuen GJ, Demissie E, Pillai S. B lymphocytes and cancer: a love-hate relationship. Trends Cancer. 2016;2(12):747-57.

[91] Lee-Chang C, Rashidi A, Miska J, Zhang $\mathrm{P}$, Pituch KC, Hou D, et al. MyeloidDerived Suppressive Cells Promote B cellMediated Immunosuppression via Transfer of PD-L1 in Glioblastoma. Cancer Immunol Res. 2019;7(12):1928-43.

[92] Ye ZP, He HY, Wang H, Li WS, Luo L, Huang ZC, et al. Glioma-derived ADAM10 induces regulatory $B$ cells to suppress CD8+ $\mathrm{T}$ cells. PLoS One. 2014;9(8):e105350.

[93] Han S, Feng S, Ren M, Ma E, Wang X, Xu $\mathrm{L}$, et al. Glioma cell-derived placental growth factor induces regulatory B cells. Int J Biochem Cell Biol. 2014;57:63-8.

[94] Savage HP, Yenson VM, Sawhney SS, Mousseau BJ, Lund FE, Baumgarth N. Blimp-1-dependent and -independent natural antibody production by B-1 and B1-derived plasma cells. J Exp Med. 2017;214(9):2777-94.

[95] Feeney AJ. Predominance of the prototypic T15 anti-phosphorylcholine junctional sequence in neonatal pre-B cells. J Immunol. 1991;147(12):4343-50.

[96] Kantor AB, Merrill CE, Herzenberg LA, Hillson JL. An unbiased analysis of V(H)$\mathrm{D}-\mathrm{J}(\mathrm{H})$ sequences from B-1a, B-1b, and conventional B cells. J Immunol. 1997;158(3):1175-86.

[97] Tornberg UC, Holmberg D. B-1a, B-1b and B-2 B cells display unique VHDJH repertoires formed at different stages of ontogeny and under different selection pressures. EMBO J. 1995;14(8):1680-9.

[98] Baumgarth N. B-cell immunophenotyping. Methods Cell Biol. 2004;75:643-62.

[99] Hernandez AM, Holodick NE. Editorial: Natural Antibodies in Health and Disease. Front Immunol. 2017;8:1795.

[100] Baumgarth N. The double life of a B-1 cell: self-reactivity selects for protective effector functions. Nat Rev Immunol. 2011;11(1):34-46.

[101] Baumgarth N. B-1 Cell Heterogeneity and the Regulation of Natural and Antigen-
Induced IgM Production. Front Immunol. 2016;7:324.

[102] Beaudin AE, Forsberg EC. To B1a or not to B1a: do hematopoietic stem cells contribute to tissue-resident immune cells? Blood. 2016;128(24):2765-9.

[103] Zhou Y, Li YS, Bandi SR, Tang L, Shinton SA, Hayakawa K, et al. Lin28b promotes fetal B lymphopoiesis through the transcription factor Arid3a. J Exp Med. 2015;212(4):569-80.

[104] Sigal NH, Pickard AR, Metcalf ES, Gearhart PJ, Klinman NR. Expression of phosphorylcholine-specific B cells during murine development. J Exp Med. 1977;146(4):933-48.

[105] Brezinschek HP, Brezinschek RI, Lipsky PE. Analysis of the heavy chain repertoire of human peripheral B cells using singlecell polymerase chain reaction. J Immunol. 1995;155(1):190-202.

[106] Brandlein S, Pohle T, Ruoff N, Wozniak E, Muller-Hermelink HK, Vollmers HP. Natural IgM antibodies and immunosurveillance mechanisms against epithelial cancer cells in humans. Cancer Res. 2003;63(22):7995-8005.

[107] Atif SM, Gibbings SL, Redente EF, Camp FA, Torres RM, Kedl RM, et al. Immune Surveillance by Natural IgM Is Required for Early Neoantigen Recognition and Initiation of Adaptive Immunity. Am J Respir Cell Mol Biol. 2018;59(5):580-91.

[108] Vollmers HP, Brandlein S. The "early birds": natural IgM antibodies and immune surveillance. Histol Histopathol. 2005;20(3):927-37.

[109] Vollmers HP, Brandlein S. Natural IgM antibodies: the orphaned molecules in immune surveillance. Adv Drug Deliv Rev. 2006;58(5-6):755-65.

[110] Diaz-Zaragoza M, Hernandez-Avila R, Viedma-Rodriguez R, Arenas-Aranda D, Ostoa-Saloma P. Natural and adaptive IgM antibodies in the recognition of tumorassociated antigens of breast cancer (Review). Oncol Rep. 2015;34(3):1106-14.

[111] Kaveri SV, Silverman GJ, Bayry J. Natural IgM in immune equilibrium and harnessing their therapeutic potential. J Immunol. 2012;188(3):939-45.

[112] Ehrenstein MR, Notley CA. The importance of natural IgM: scavenger, protector and regulator. Nat Rev Immunol. 2010;10(11):778-86.

[113] Boes M, Schmidt T, Linkemann K, Beaudette BC, Marshak-Rothstein A, Chen J. Accelerated development of $\mathrm{IgG}$ autoantibodies and autoimmune disease in 
the absence of secreted $\operatorname{IgM}$. Proc Natl Acad Sci U S A. 2000;97(3):1184-9.

[114] Vollmers HP, Brandlein S. Natural IgM antibodies: from parias to parvenus. Histol Histopathol. 2006;21(12):1355-66.

[115] Chou MY, Fogelstrand L, Hartvigsen K, Hansen LF, Woelkers D, Shaw PX, et al. Oxidation-specific epitopes are dominant targets of innate natural antibodies in mice and humans. J Clin Invest. 2009;119(5):1335-49.

[116] Gronwall C, Silverman GJ. Natural IgM: beneficial autoantibodies for the control of inflammatory and autoimmune disease. J Clin Immunol. 2014;34 Suppl 1:S12-21.

[117] Becker Y, Forster S, Gielen GH, Loke I, Thaysen-Andersen M, Laurini C, et al. Paucimannosidic glycoepitopes inhibit tumorigenic processes in glioblastoma multiforme.

Oncotarget. 2019;10(43):4449-65.

[118] Dawn M. Ecker TJC, Patricia Seymour. Bioprocess International [Internet]. Boston: Bioprocess International. 2020. Available from: https://bioprocessintl.com/business/econo mics/the-market-for-therapeutic-mabproducts/.

[119] Wire B. Global Monoclonal Antibodies (mAbs) Market Report 2020 with Profiles of Johnson \& Johnson, Merck, AbbVie, Amgen, Glaxosmithkline

ResearchAndMarkets.com. 2019.

[120] Hensel F, Eckstein M, Rosenwald A, Brandlein S. Early development of PATSM6 for the treatment of melanoma. Melanoma Res. 2013;23(4):264-75.

[121] Rasche L, Duell J, Castro IC, Dubljevic V, Chatterjee M, Knop S, et al. GRP78directed immunotherapy in relapsed or refractory multiple myeloma - results from a phase 1 trial with the monoclonal immunoglobulin M antibody PAT-SM6. Haematologica. 2015;100(3):377-84.

[122] A Safety and Pharmacokinetic Study of IGM-2323 in Subjects With Relapsed/Refractory Non-Hodgkin Lymphoma [Internet]. IGM Biosciences, Inc. 2021 [cited May 29, 2021]. Available from:

https://clinicaltrials.gov/ct2/show/NCT040 82936?term=Immunoglobulin+M\%2C+Ig M\&cond=Cancer\&intr=Antibody $\% 2 \mathrm{C}+\mathrm{Ig}$ M\&draw=2\&rank=4.

[123] Skarzynski M, Vire B, Thomas J, Nelson C, David A, Aue G, et al. Novel IgMderived antibody-drug conjugate selectively kills chronic lymphocytic leukemia cells through binding of $\mathrm{Fc} \mu$ receptor leading to rapid internalization and intracellular cytotoxic payload delivery (VAC3P.953). The Journal of Immunology. 2014;192(1 Supplement):73.15-73.15.

[124] Carter PJ, Lazar GA. Next generation antibody drugs: pursuit of the 'highhanging fruit'. Nat Rev Drug Discov. 2018;17(3):197-223.

[125] Zahavi D, Weiner L. Monoclonal Antibodies in Cancer Therapy. Antibodies (Basel). 2020;9(3).

[126] Hiramoto E, Tsutsumi A, Suzuki R, Matsuoka S, Arai S, Kikkawa M, et al. The $\operatorname{IgM}$ pentamer is an asymmetric pentagon with an open groove that binds the AIM protein. Sci Adv. 2018;4(10):eaau1199.

[127] Hakomori S. Tumor-associated carbohydrate antigens defining tumor malignancy: basis for development of anticancer vaccines. Adv Exp Med Biol. 2001;491:369-402.

[128] Akhouri RR, Goel S, Furusho H, Skoglund U, Wahlgren M. Architecture of Human IgM in Complex with $\mathrm{P}$. falciparum Erythrocyte Membrane Protein 1. Cell Rep. 2016;14(4):723-36.

[129] Muthana SM, Xia L, Campbell CT, Zhang Y, Gildersleeve JC. Competition between serum IgG, IgM, and IgA anti-glycan antibodies. PLoS One. 2015;10(3):e0119298.

[130] Oyelaran O, Li Q, Farnsworth D, Gildersleeve JC. Microarrays with varying carbohydrate density reveal distinct subpopulations of serum antibodies. J Proteome Res. 2009;8(7):3529-38.

[131] Samsudin F, Yeo JY, Gan SK, Bond PJ. Not all therapeutic antibody isotypes are equal: the case of $\operatorname{IgM}$ versus $\operatorname{IgG}$ in Pertuzumab and Trastuzumab. Chem Sci. 2020;11(10):2843-54.

[132] Hensel F, Hermann R, Brandlein S, Krenn $\mathrm{V}$, Schmausser B, Geis S, et al. Regulation of the new coexpressed CD55 (decayaccelerating factor) receptor on stomach carcinoma cells involved in antibody SC-1induced apoptosis. Lab Invest. 2001;81(11):1553-63.

[133] Harkonen S, Scannon P, Mischak RP, Spitler LE, Foxall C, Kennedy D, et al. Phase I study of a murine monoclonal antilipid A antibody in bacteremic and nonbacteremic patients. Antimicrob Agents Chemother. 1988;32(5):710-6.

[134] Fisher CJ, Jr., Zimmerman J, Khazaeli MB, Albertson TE, Dellinger RP, Panacek EA, et al. Initial evaluation of human monoclonal anti-lipid A antibody (HA-1A) in patients with sepsis syndrome. Crit Care Med. 1990;18(12):1311-5. 
[135] Daifuku R, Haenftling K, Young J, Groves ES, Turrell C, Meyers FJ. Phase I study of antilipopolysaccharide human monoclonal antibody MAB-T88. Antimicrob Agents Chemother. 1992;36(10):2349-51.

[136] Line BR, Breyer RJ, McElvany KD, Earle DC, Khazaeli MB. Evaluation of human anti-mouse antibody response in normal volunteers following repeated injections of fanolesomab (NeutroSpec), a murine antiCD15 IgM monoclonal antibody for imaging infection. Nucl Med Commun. 2004;25(8):807-11.

[137] Hensel F, Timmermann W, von Rahden BH, Rosenwald A, Brandlein S, Illert B. Ten-year follow-up of a prospective trial for the targeted therapy of gastric cancer with the human monoclonal antibody PATSC1. Oncol Rep. 2014;31(3):1059-66.

[138] Liedtke M, Twist CJ, Medeiros BC, Gotlib JR, Berube C, Bieber MM, et al. Phase I trial of a novel human monoclonal antibody mAb216 in patients with relapsed or refractory B-cell acute lymphoblastic leukemia. Haematologica. 2012;97(1):307.

[139] Irie RF, Ollila DW, O'Day S, Morton DL. Phase I pilot clinical trial of human IgM monoclonal antibody to ganglioside GM3 in patients with metastatic melanoma. Cancer Immunol Immunother. 2004;53(2):110-7.

[140] Safety Study of Human IgM (MORAb028) to Treat Metastatic Melanoma. [Internet]. [cited 20 May 2021].

[141] Eisen A, Greenberg BM, Bowen JD, Arnold DL, Caggiano AO. A double-blind, placebo-controlled, single ascending-dose study of remyelinating antibody $\mathrm{rHIgM} 22$ in people with multiple sclerosis. Mult Scler J Exp Transl Clin. 2017;3(4):2055217317743097.

[142] Heimburg-Molinaro J, Rittenhouse-Olson K. Development and characterization of antibodies to carbohydrate antigens. Methods Mol Biol. 2009;534:341-57.

[143] Enoksson SL, Grasset EK, Hagglof T, Mattsson N, Kaiser Y, Gabrielsson S, et al. The inflammatory cytokine IL-18 induces self-reactive innate antibody responses regulated by natural killer T cells. Proc Natl Acad Sci U S A. 2011;108(51):E1399-407.

[144] Kinoshita M, Shinomiya N, Ono S, Tsujimoto H, Kawabata T, Matsumoto A, et al. Restoration of natural IgM production from liver B cells by exogenous IL-18 improves the survival of burn-injured mice infected with Pseudomonas aeruginosa. J Immunol. 2006;177(7):4627-35.
[145] Warrington AE, Bieber AJ, Van Keulen V, Ciric B, Pease LR, Rodriguez M. Neuronbinding human monoclonal antibodies support central nervous system neurite extension. J Neuropathol Exp Neurol. 2004;63(5):461-73.

[146] Dykstra KH, Arya A, Arriola DM, Bungay PM, Morrison PF, Dedrick RL. Microdialysis study of zidovudine (AZT) transport in rat brain. J Pharmacol Exp Ther. 1993;267(3):1227-36.

[147] Morrison PF, Laske DW, Bobo H, Oldfield EH, Dedrick RL. High-flow microinfusion: tissue penetration and pharmacodynamics. Am J Physiol. 1994;266(1 Pt 2):R292-305.

[148] Krewson CE, Klarman ML, Saltzman WM. Distribution of nerve growth factor following direct delivery to brain interstitium. Brain Res. 1995;680(12):196-206.

[149] Louveau A, Smirnov I, Keyes TJ, Eccles JD, Rouhani SJ, Peske JD, et al. Structural and functional features of central nervous system lymphatic vessels. Nature. 2015;523(7560):337-41.

[150] Larson SM, Carrasquillo JA, Cheung NK, Press OW. Radioimmunotherapy of human tumours. Nat Rev Cancer. 2015;15(6):34760 .

[151] Rizk ML, Zou L, Savic RM, Dooley KE. Importance of Drug Pharmacokinetics at the Site of Action. Clin Transl Sci. 2017;10(3):133-42.

[152] Neuwelt EA, Hill SA, Frenkel EP, Diehl JT, Maravilla KR, Vu LH, et al. Osmotic blood-brain barrier disruption: pharmacodynamic studies in dogs and a clinical phase I trial in patients with malignant brain tumors. Cancer Treat Rep. 1981;65 Suppl 2:39-43.

[153] Rapoport SI. Effect of concentrated solutions on blood-brain barrier. Am J Physiol. 1970;219(1):270-4.

[154] Siegal T, Rubinstein R, Bokstein F, Schwartz A, Lossos A, Shalom E, et al. In vivo assessment of the window of barrier opening after osmotic blood-brain barrier disruption in humans. $\mathbf{J}$ Neurosurg. 2000;92(4):599-605.

[155] Raymond JJ, Robertson DM, Dinsdale HB. Pharmacological modification of bradykinin induced breakdown of the blood-brain barrier. Can J Neurol Sci. 1986;13(3):214-20.

[156] Warren K, Jakacki R, Widemann B, Aikin A, Libucha M, Packer R, et al. Phase II trial of intravenous lobradimil and carboplatin in childhood brain tumors: a report from the Children's Oncology Group. Cancer Chemother Pharmacol. 2006;58(3):343-7. 
[157] Hynynen K, McDannold N, Sheikov NA, Jolesz FA, Vykhodtseva N. Local and reversible blood-brain barrier disruption by noninvasive focused ultrasound at frequencies suitable for trans-skull sonications. Neuroimage. 2005;24(1):1220.

[158] Vykhodtseva NI, Hynynen K, Damianou C. Histologic effects of high intensity pulsed ultrasound exposure with subharmonic emission in rabbit brain in vivo. Ultrasound Med Biol. 1995;21(7):969-79.

[159] Janowicz PW, Leinenga G, Gotz J, Nisbet RM. Ultrasound-mediated blood-brain barrier opening enhances delivery of therapeutically relevant formats of a tauspecific antibody. Sci Rep. 2019;9(1):9255.

[160] Goutal S, Gerstenmayer M, Auvity S, Caille F, Meriaux S, Buvat I, et al. Physical blood-brain barrier disruption induced by focused ultrasound does not overcome the transporter-mediated efflux of erlotinib. J Control Release. 2018;292:210-20.

[161] Kung Y, Huang HY, Liao WH, Huang AP, Hsiao MY, Wu CH, et al. A Single HighIntensity Shock Wave Pulse With Microbubbles Opens the Blood-Brain Barrier in Rats. Front Bioeng Biotechnol. 2020;8:402.

[162] Cohen-Inbar O, Xu Z, Sheehan JP. Focused ultrasound-aided immunomodulation in glioblastoma multiforme: a therapeutic concept. J Ther Ultrasound. 2016;4:2.

[163] Manallack DT. The pK(a) Distribution of Drugs: Application to Drug Discovery. Perspect Medicin Chem. 2007;1:25-38.

[164] Nagpal K, Singh SK, Mishra DN. Drug targeting to brain: a systematic approach to study the factors, parameters and approaches for prediction of permeability of drugs across BBB. Expert Opin Drug Deliv. 2013;10(7):927-55.

[165] Meng J, Agrahari V, Youm I. Advances in Targeted Drug Delivery Approaches for the Central Nervous System Tumors: The Inspiration of Nanobiotechnology. J Neuroimmune Pharmacol. 2017;12(1):8498.

[166] White BD, Duan C, Townley HE. Nanoparticle Activation Methods in Cancer Treatment. Biomolecules. 2019;9(5).
[167] Luo M, Lewik G, Ratcliffe JC, Choi CHJ, Makila E, Tong WY, et al. Systematic Evaluation of Transferrin-Modified Porous Silicon Nanoparticles for Targeted Delivery of Doxorubicin to Glioblastoma. ACS Appl Mater Interfaces. 2019;11(37):33637-49.

[168] Jena L, McErlean E, McCarthy H. Delivery across the blood-brain barrier: nanomedicine for glioblastoma multiforme. Drug Deliv Transl Res. 2020;10(2):304-18.

[169] Guo L, Ren J, Jiang X. Perspectives on brain-targeting drug delivery systems. Curr Pharm Biotechnol. 2012;13(12):2310-8.

[170] Pardridge WM. Delivery of Biologics Across the Blood-Brain Barrier with Molecular Trojan Horse Technology. BioDrugs. 2017;31(6):503-19.

[171] Ullman JC, Arguello A, Getz JA, Bhalla A, Mahon CS, Wang J, et al. Brain delivery and activity of a lysosomal enzyme using a blood-brain barrier transport vehicle in mice. Sci Transl Med. 2020;12(545).

[172] Kariolis MS, Wells RC, Getz JA, Kwan W, Mahon CS, Tong R, et al. Brain delivery of therapeutic proteins using an $\mathrm{Fc}$ fragment blood-brain barrier transport vehicle in mice and monkeys. Sci Transl Med. 2020;12(545).

[173] Yu YJ, Atwal JK, Zhang Y, Tong RK, Wildsmith KR, Tan C, et al. Therapeutic bispecific antibodies cross the blood-brain barrier in nonhuman primates. Sci Transl Med. 2014;6(261):261ra154.

[174] Boado RJ, Zhang Y, Zhang Y, Pardridge WM. Humanization of anti-human insulin receptor antibody for drug targeting across the human blood-brain barrier. Biotechnol Bioeng. 2007;96(2):381-91.

[175] Niewoehner J, Bohrmann B, Collin L, Urich E, Sade H, Maier P, et al. Increased brain penetration and potency of a therapeutic antibody using a monovalent molecular shuttle. Neuron. 2014;81(1):4960.

[176] Galstyan A, Markman JL, Shatalova ES, Chiechi A, Korman AJ, Patil R, et al. Blood-brain barrier permeable nano immunoconjugates induce local immune responses for glioma therapy. Nat Commun. 2019;10(1):3850. 